\title{
Tamilokus mabinia, a new, anatomically divergent genus and species of wood-boring bivalve from the Philippines
}

\author{
J. Reuben Shipway ${ }^{1}$, Marvin A Altamia ${ }^{1}$, Gary Rosenberg ${ }^{2}$, Gisela P Concepcion ${ }^{3}$, Margo G Haygood ${ }^{4}$, \\ Daniel L Distel Corresp. 1 \\ ${ }^{1}$ Ocean Genome Legacy Center, Department of Marine and Environmental Science, Northeastern University, Nahant, MA, United States of America \\ 2 Academy of Natural Sciences, Drexel University, Philadelphia, PA, United States of America \\ 3 Marine Science Institute, University of the Philippines, Quezon City, Philippines \\ 4 Department of Medicinal Chemistry, University of Utah, Salt Lake City, UT, United States of America \\ Corresponding Author: Daniel L Distel \\ Email address: d.distel@northeastern.edu
}

Here we describe an anatomically divergent wood-boring bivalve belonging to the family Teredinidae. Specimens were collected off the coast of Mabini, Batangas, Philippines, in February 2018, from sunken driftwood at a depth of less than $2 \mathrm{~m}$. A combination of characteristics differentiates these specimens from members of previously named teredinid genera and species. Most notable among these include: an enlarged cephalic hood which extends across the posterior slope of the shell valves and integrates into the posterior adductor muscle; a unique structure, which we term the 'cephalic collar', formed by protruding folds of the mantle immediately ventral to the foot and extending past the posterior margin of the valves; a large globular stomach located entirely posterior to the posterior adductor muscle and extending substantially beyond the posterior gape of the valves; an elongate crystalline style and style sac extending from the base of the foot, past the posterior adductor muscle, to the posteriorly located stomach; calcareous pallets distinct from those of described genera; a prominently flared mantle collar which extends midway along the stalk of the pallets; and, separated siphons that bear a pigmented pinstripe pattern with highly elaborate compound papillae on the incurrent siphon aperture. We used Micro-Computed Tomography (Micro-CT) to build a virtual 3D anatomical model of this organism, confirming the spatial arrangement of the structures described above. Phylogenetic analysis of the small (18S) and large (28S) nuclear rRNA gene sequences, place this bivalve within the Teredindae on a branch well differentiated from previously named genera and species. We propose the new genus and species Tamilokus mabinia to accommodate these organisms, raising the total number of genera in this economically and environmentally important family to 16 . This study demonstrates the efficacy of Micro-CT for anatomical description of a systematically challenging group of bivalves whose highly derived body plans are differentiated predominantly by soft tissue 
adaptations rather than features of calcareous hard-parts. 
1 Title: Tamilokus mabinia, a new, anatomically divergent genus and species of wood-boring

2 bivalve from the Philippines.

4 Short title: $T$. mabinia, a new Philippine shipworm

5

6 Authors: J. Reuben Shipway ${ }^{1}$, Marvin A. Altamia ${ }^{1}$ Gary Rosenberg $^{2}$, Gisela P. Concepcion ${ }^{3}$,

7 Margo G. Haygood ${ }^{4} \&$ Daniel L. Distel ${ }^{1 *}$

8

9 Author affiliations: ${ }^{1}$ Ocean Genome Legacy Center, Department of Marine and Environmental

10 Science, Northeastern University, Nahant, MA, USA; ${ }^{2}$ Academy of Natural Sciences, Drexel

11 University, Philadelphia, PA, USA; ${ }^{3}$ Marine Science Institute, University of the Philippines,

12 Quezon City, Philippines; ${ }^{4}$ Department of Medicinal Chemistry, University of Utah, Salt Lake

13 City, UT, USA.

$14 *$ d.distel@,northeastern.edu to whom correspondence should be directed

\section{Abstract}

17 Here we describe an anatomically divergent wood-boring bivalve belonging to the family

18 Teredinidae. Specimens were collected off the coast of Mabini, Batangas, Philippines, in

19 February 2018, from sunken driftwood at a depth of less than $2 \mathrm{~m}$. A combination of characteristics differentiates these specimens from members of named teredinid genera and species. Most notable among these include: an enlarged cephalic hood which extends across the posterior slope of the shell valves and integrates into the posterior adductor muscle; a unique 
23 structure, which we term the 'cephalic collar', formed by protruding folds of the mantle

24 immediately ventral to the foot and extending past the posterior margin of the valves; a large

25 globular stomach located entirely posterior to the posterior adductor muscle and extending

26 substantially beyond the posterior gape of the valves; an elongate crystalline style and style sac

27 extending from the base of the foot, past the posterior adductor muscle, to the posteriorly located

28 stomach; calcareous pallets distinct from those of described genera; a prominently flared mantle

29 collar which extends midway along the stalk of the pallets; and, separated siphons that bear a

30 pigmented pinstripe pattern with highly elaborate compound papillae on the incurrent siphon

31 aperture. We used Micro-Computed Tomography (Micro-CT) to build a virtual 3D anatomical

32 model of this organism, confirming the spatial arrangement of the structures described above.

33 Phylogenetic analysis of the small (18S) and large (28S) nuclear rRNA gene sequences, place

34 this bivalve within the Teredindae on a branch well differentiated from named genera and

35 species. We propose the new genus and species Tamilokus mabinia to accommodate these

36 organisms, raising the total number of genera in this economically and environmentally

37 important family to 17 . This study demonstrates the efficacy of Micro-CT for anatomical

38 description of a systematically challenging group of bivalves whose highly derived body plans

39 are differentiated predominantly by soft tissue adaptations rather than features of calcareous

40 hard-parts.

41

42 urn:Isid:zoobank.org:pub:0235E48D-D7B7-4A4B-A078-4204C1907240

43

44

\section{Introduction}

The Teredinidae, commonly referred to as shipworms, are a group of wood-boring bivalves with wide-ranging economic and ecological impacts in coastal marine systems. Their ability to bore 
46 into and digest wood is estimated to cause billions of dollars in damage per year to coastal

47 structures, such as piers, jetties, wharfs, fishing equipment and aquaculture pens (Turner (1966),

48 Distel 2003). Yet this same ability allows them to play a fundamental role in carbon cycling by

49 processing recalcitrant organic carbon trapped in wood and liberating nutrients and energy that

50 would otherwise be less accessible to other organisms (Nishimoto et al. 2015, Charles et al.

51 2016).

53 The unique wood-boring life-style of the Teredinidae has led to several anatomical

54 specialisations and as such, this family is believed to exhibit more variation in morphology than any other group in the Mollusca (Turner 1988). In contrast to more typical bivalves, the shell is greatly reduced in size and has prominent pedal and posterior gapes, allowing the protrusion of the foot and elongate body respectively. The location of the shell valves at the extreme anterior end of the body covers little of the visceral mass and offers little or no protection to the animal. Instead, the shell, which features tiny denticulated ridges on its surface, functions as an effective drilling and grinding tool for burrowing into wood (Nair 1966, Turner 1966, Voight 2015). The body is long, vermiform and enclosed by a calcareous tube that is secreted onto the burrow walls, surrounding the animal from the posterior edge of the valves to the burrow opening. The siphons are flanked by a pair of calcareous, paddle or feather-like structures, known as the pallets. These pallets, which are unique to Teredinidae, serve as watertight and predator-resistant plugs to seal the burrow entrance (Nair 1966, Turner 1966, Voight 2015). Currently, there are 16 accepted genera composed of 70 species in the Teredinidae (Bulatov 1933, Turner 1966, Macintosh 2012,

67 BORGES et al. 2018, Velásquez et al. 2018). However, it has been recently suggested that between 80-100 species likely exist (Huber et al. 2015, Shipway et al. 2016). 
70

Using integrative taxonomic methods, including anatomical, morphological and molecular data (Borges et al. 2012, Shipway, O'Connor et al. 2016), we identify and describe a new species and genus of wood-boring teredinid from the Philippines, which we name Tamilokus mabinia.

\section{Materials \& Methods}

\section{Specimen Collection}

Nine specimens of Tamilokus mabinia were collected in February 2018 off the coast of Balayan Bay, Mabini, Batangas, Philippines $\left(13.758^{\circ} \mathrm{N}, 120.925^{\circ} \mathrm{E}\right)$, at a depth of $<2 \mathrm{~m}$, from a $\log$ measuring approximately $2 \mathrm{~m}$ in total length, as part of the Philippine Mollusk Symbiont (PMS) International Collaborative Biodiversity Group (ICBG) expedition. The specimen location map (Fig. 1) was produced and approximate coordinates were determined using the National Oceanographic and Atmospheric Administration Map Viewer (https://www.nauticalcharts.noaa.gov/ENCOnline/enconline.html). Specimens were carefully extracted from their burrows, photographed (Fig. 2), measured, fixed in $4 \%$ formaldehyde solution freshly prepared from paraformaldehyde (PFA), washed, and dehydrated through an ethanol series (30\%, 50\% and 70\%, 30 minutes per wash, $\mathrm{x} 2$ washes) with final storage in $70 \%$ ethanol. Partial specimens, identifiable as T. mabinia based on the unique morphology of the pallets, siphons and cephalic collar, were dissected or were fixed in 100\% ethanol for DNA preservation. Morphological features (Fig. 3) and calcareous structures (Fig. 4) were imaged using the Keyence VHX-6000 Digital Microscope (Osaka, Japan). Specimens were directly compared with all described teredinid genera from the Harvard Museum of Comparative Zoology. Part of this work was completed under the supervision of the Department of 
92 Agriculture-Bureau of Fisheries and Aquatic Resources, Philippines (DA-BFAR) in compliance

93 with all required legal instruments and regulatory issuances covering the conduct of the research.

94 All Philippine specimens used in this study were obtained using Gratuitous Permit GP-0140-17

95 issued by DA-BFAR.

96

97

Micro-Computed Tomography

98

99

100

101

102

103

104

105

106

107

108

109

110

111

112

113

Specimen PMS-4051L was stained for 20 days in 10\% iodine prior to imaging. Imaging was performed using a SkyScan $1173 \mu \mathrm{CT}$ scanner (Bruker Micro-CT, Kontich, Belgium) equipped with a Hamamatsu 130/300 tungsten X-ray source and a FlatPanel Sensor camera detector with $2240 \times 2240$ pixels. Scanning parameters were as follows: source voltage $=60 \mathrm{kV}$; source current $=100 \mu \mathrm{A}$; exposure time $=900 \mathrm{~ms}$; frames averaged $=3$; frames acquired over $180^{\circ}=960$; filter $=$ no; binning $=$ no; flat field correction $=$ activated; scanning time $=(x 3) 00: 28: 14$; number of connected $\operatorname{scans}=3$; and, random movement $=\mathrm{ON}(10)$. Reconstruction of the raw data was accomplished using the software provided with the scanner (NRecon 1.6.6.0, Bruker Micro-CT, Kontich, Belgium). The following settings were employed to enhance image contrast and to compensate for ring and streak artefacts; smoothing=no, ring artefact correction=4, and beam hardening correction =activated. Reconstructed scans were then analyzed using CTVox (Bruker Micro-CT, Kontich, Belgium). A Micro-CT 3D rendered model of Tamilokus mabinia, including major anatomical structures and transverse cross sections of the model is shown in Figure 5. 
114 DNA was extracted from the siphonal tissue and associated musculature from one specimen of

115 Tamilokus mabinia (PMS-3943P), using the DNeasy Blood \& Tissue kit (Qiagen, Hilden,

116 Germany) following manufacturer's protocol. Approximate purity, concentration and yield of

117 DNA were determined by UV spectrophotometry. Genomic DNA was cryo-preserved at $-80{ }^{\circ} \mathrm{C}$

118 and archived at the Ocean Genome Legacy Center of New England Biolabs, Northeastern

119 University, Nahant, MA, USA (accession number in Table1). The small (18S) and large (28S)

120 subunit nuclear rRNA genes were amplified from the resultant DNA preparation by polymerase

121 chain reaction (PCR). Amplification reactions were prepared using $12.5 \mu \mathrm{L}$ of high-fidelity

122 polymerase solution (OneTaq, New England Biolabs, Ipswich, Massachusetts), $0.5 \mu \mathrm{L}$ of each

123 primer $(10 \mathrm{mM}), 1-2 \mu \mathrm{L}$ DNA template $(10-20 \mathrm{ng} / \mu \mathrm{L})$, brought to a total volume of $25 \mu \mathrm{L}$ with

124 purified water. Fragments of the small (18S) and large (28S) subunit nuclear rRNA genes were

125 amplified using the primer pairs 18S EukF (5'-WAY-CTG-GTT-GAT-CCT-GCC-AGT -3') and

126 18S EukR (5'-TGA-TCC-TTC-YGC-AGG-TTC-ACC-TAC-3') (Medlin et al. 1988); 28S-

127 NLF184-21 (5' - ACC-CGC-TGA-AYT-TAA-GCA-TAT -3') and 28S-1600R (5' -AGC-GCC-

ATC-CAT-TTT-CAG-G -3') (Distel et al. 2011), resulting in amplicons of approximately 1,686

and 1,416 base pairs, respectively. The PCR amplification proceeded as follows: an initial

denaturation step of $94^{\circ} \mathrm{C}$ for three minutes, followed by 35 cycles with a denaturation step of

$94{ }^{\circ} \mathrm{C}$ for $20 \mathrm{~s}$, an annealing step of $64{ }^{\circ} \mathrm{C}$ for $40 \mathrm{~s}$ for the $18 \mathrm{~S}$ and $63{ }^{\circ} \mathrm{C}$ for $30 \mathrm{~s}$ for $28 \mathrm{~S}$, an

extension step of $68^{\circ} \mathrm{C}$ for $60 \mathrm{~s}$ and a final extension of $68^{\circ} \mathrm{C}$ for five minutes. All reactions

were performed on a PTC-200 Thermal Cycler (MJ Research, Quebec, Canada).

For each template, three separate amplicons, all produced under identical conditions, were

136 pooled, cleaned and concentrated using the Zymo Clean \& Concentrator Kit (Irvine, CA). 
137 Resulting products were sequenced bidirectionally on a 3730xl DNA Analyzer (Life

138 Technologies, Grand Island, NY) using the Big Dye Terminator 3.1 Cycle Sequencing Kit (Life

139 Technologies, Grand Island, NY) at New England Biolabs (Ipswich, Massachusetts). Primary

140 sequence data from the small (18S) and large (28S) subunit nuclear rRNA genes were submitted

141 to GenBank (NCBI) under accession numbers MH974682 and MH974683, respectively.

\section{Phylogenetic Analysis}

144 The 18S and 28S rRNA gene sequences from specimen PMS-3943P were concatenated and 145 aligned as in Distel et al. (Distel, Amin et al. 2011) with sequences representing 10 of 16 146 recognized genera (Bulatov 1933, Turner 1966) including: Bankia Gray 1842, Dicyathifer 147 Iredale 1932, Kuphus Guettard 1770, Lyrodus Gould 1870, Nausitora Wright 1864, Neoteredo 148 Bartsch 1920, Spathoteredo Moll 1928, Teredo Linnaeus 1758, Teredora Bartsch 1921, and 149 Teredothyra Bartsch 1921. Phylogenetic analysis was performed using MrBayes version 3.2.6 150 (Ronquist et al. 2003) implemented at Geneious version 10.2.2 (https://www.geneious.com) 151 using GTR $+\mathrm{I}+\Gamma$ nucleotide substitution model. Placopecten magellanicus was specified as the 152 outgroup, the chain length was set to 5 million, subsampling every 2,000 generations and 153 discarding the first $20 \%$ of the results as burn-in.

154

\section{Zoobank Registration}

156 The electronic version of this article in Portable Document Format (PDF) will represent a 157 published work according to the International Commission on Zoological Nomenclature (ICZN), 158 and hence the new names contained in the electronic version are effectively published under that 159 Code from the electronic edition alone. This published work and the nomenclatural acts it 
160 contains have been registered in ZooBank, the online registration system for the ICZN. The

161 ZooBank LSIDs (Life Science Identifiers) can be resolved and the associated information viewed

162 through any standard web browser by appending the LSID to the prefix http://zoobank.org/. The

163 LSID for this publication is: LSID urn:1sid:zoobank.org:pub:0235E48D-D7B7-4A4B-A078-

164 4204C1907240. The online version of this work is archived and available from the following 165 digital repositories: PeerJ, PubMed Central and CLOCKSS.

167 Results

168 Systematics

169 Family Teredinidae Rafinesque, 1815

170 Tamilokus Shipway, Distel \& Rosenberg, gen. nov.

171 urn:1sid:zoobank.org:act:61B916B1-54D1-418D-B1A3-342162C261C2

172 Type species: Tamilokus mabinia sp. nov.

173 Type material: Holotype PMS-3916Y; paratypes PMS-3899P, PMS-3915X, PMS-3943P, PMS-

174 3949Y, PMS-4037Y, and PMS-4051L. Smallest to largest specimens measured $6.2 \mathrm{~cm}-15.4 \mathrm{~cm}$

175 in total body length. The holotype is currently held at the Academy of Natural Sciences of

176 Philadelphia (ANSP) and will be deposited in the National Museum of the Philippines in Manila

177 pending completion of an ongoing reorganization. Paratypes are deposited at ANSP, at the

178 Marine Science Institute of the University of the Philippines (MSI) and at the Ocean Genome

179 Legacy Center of New England Biolabs, Northeastern University (OGL). For catalog numbers

180 assigned by holding institutions see Table 1. 
181 Type locality: Balayan Bay, off Mabini, Batangas Province, Philippines (coordinates $13.758^{\circ} \mathrm{N}$, $\left.182120.925^{\circ} \mathrm{E}\right)$.

183 Comparative Material: The following material was examined: Teredora malleolus (Turton, 184 1822) MCZ-350541 (3 specimens); Teredora princesae (Sivickis, 1928) MCZ-232090 (5

185 specimens); Uperotus clava (Gmelin, 1791) MCZ-238009 (3 specimens); and, Uperotus panamensis (Bartsch, 1922) MCZ-357824 (4 specimens).

Diagnosis: pallets triangular-shaped with an ovate, flattened stalk, prominent cephalic hood and cephalic crest, crystalline style extends beyond posterior adductor muscle, caecum U-shaped doubling back upon itself, siphons with distinct pin-striped pigmentation with incurrent siphon featuring three rows of papillae

Etymology: Tamilokus (masculine), in recognition of the common name for shipworm in the Philippines, 'tamilok'.

Habitat: Marine, wood-borer.

Description: Pallets very small in relation to body length (Figs. 2A \& 3A), formed of a broad, flattened, translucent and ovate stalk, with a solid, white calcareous blade (Fig. 4A); cephalic hood prominent, extending to cover the posterior slope of the shell valves (Figs. 2A, 3A-C \& 5A, C); "cephalic collar", formed from protruding folds of the mantle, extending along the ventral surface from the base of the foot to a point slightly posterior to the posterior margin of the shell valves (Figs. 2A-B, 3A, D-E, 5A-B); large crystalline style and style sac originating within the cephalic collar and extending beyond the posterior adductor muscle into the posteriorly located stomach (Figs. 5A-E); large globular stomach (Figs. 2A-B \& 5A, E-F) located posteriorly in relation to posterior adductor muscle and valve pedal gape, composed of three lobes, with 
203 muscular opening into caecum (Figs. 5A, F); large digestive glands (Figs. 2A-C \& Figs. 5A, C-

204 E); caecum (Figs. 2A-C \& 5A, D-I) large, elongate, U-shaped, doubling back upon itself

205 anteriorly towards the right (Fig. 2B \&5D-I), lacking a typhlosole (Figs. 5D-I); intestine

206 unusually broad and voluminous (Fig. 2B), especially where it passes ventral to the caecum

207 (Figs. 5G-I), containing short ovoid faecal pellets packed in multiple rows across its width (Fig.

208 2B); intestine extends anteriorly, looping over crystalline style sac (Figs. 5C-E), then doubles

209 back posteriorly, looping under the caecum before extending anteriorly on the dorsal surface of

210 the caecum, finally looping under the posterior adductor muscle before extending a short

211 distance posteriorly and opening into the anal canal; anal canal is open and does not retain

212 faeces; gonad located centrally (Figs. 5A, I-K), beginning posterior to the caecum and ending at

213 the heart; heart located medially (Figs. 5J-K); gill extends from the siphons anteriorly to the

214 posterior tip of the gonads (Figs. 5A, K-L); prominently flared mantle collar around siphons and

215 pallets (Figs. 2B, 3A \& 5A).

216 Remarks: Tamilokus gen. nov may be easily differentiated from all other genera within the

217 family Teredinidae based on pallet morphology. The simple triangular cup-shaped pallet and

218 thick ovate stalk of Tamilokus may be distinguished from the pallets of: Bankia Gray 1842,

219 Nausitora Wright 1864, Nototeredo Bartsch 1923, and Spathoteredo Moll 1928 by the lack of

220 segmentation; from Lyrodus Gould 1870, Teredo Linnaeus 1758, Zachsia Bulatoff \&

221 Rjabtschikoff 1933, and Nivanteredo Velásquez \& Shipway 2018 by the absence of a

222 periostracum and presence of a broad ovate stalk; from Teredothyra Bartsch 1921 by the

223 presence of a single undivided cup; from Dicyathifer Iredale 1932 and Kuphus Guettard 1770 by

224 the absence of a medial ridge; from Bactronophorus Tapparone Canefri 1877 by the absence of a

225 dagger-like extension; from Neoteredo Bartsch 1920, Psiloteredo Bartsch 1922, Teredora 
226 Bartsch 1921 and Uperotus Guettard 1770 by the cup- rather than paddle-shaped blades, and

227 from the latter three genera by the lack a distinct thumb-nail like depression bearing concentric

228 or radiating ridges.

Additionally, Tamilokus may be easily distinguished from Bactronophorus Tapparone Canefri

231

232

233

234

235

236

237

238

239

240

241

242

243

244

245

246

247

1877, Dicyathifer Iredale 1932, Neoteredo Bartsch 1920 and Teredothyra Bartsch 1921 by the absence of a muscular sphincter at the posterior end of the anal canal; from Lyrodus Gould 1870, Teredo Linnaeus 1758 and Zachsia Bulatoff \& Rjabtschikoff 1933 by the absence of brood pouches on the gill; from Neoteredo Bartsch 1920 by the absence of dorsal lappets; and from Kuphus Guettard 1770 by the presence of a caecum and the absence of a strong muscular collar surrounding the valves.

\section{Tamilokus is similar to Teredora Bartsch 1921 and Uperotus Guettard 1770 in that it possesses a} U-shaped caecum that, after passing posteriorly from the stomach, doubles back upon itself towards the right and extends anteriorly, terminating near its origin on the right side of the stomach (Turner, 1966). However, Tamilokus can be easily distinguished from these genera based on pallet morphology (as previously described). Additionally, the gills of Teredora and Uperotus extend the entire length of the animal from the base of the siphons to the mouth, whereas those of Tamilokus terminate near the posterior end of the caecum; the labial palps in both Teredora and Uperotus are large and free, but are very small and attached in Tamilokus; the crystalline style in both Teredora and Uperotus is located anteriorly to the posterior adductor muscle, but extends from the base of the foot well beyond the posterior margin of the adductor 
248 muscle in Tamilokus; the stomach of both Teredora and Uperotus is located anterior to posterior

249 adductor muscle, whereas the stomach of Tamilokus is located posterior to the posterior adductor

250 muscle; the heart of both Teredora and Uperotus is positioned anteriorly, but is medially

251 positioned in Tamilokus; the siphons of Teredora and Uperotus are united along their entire

252 length, but are separate in Tamilokus; the incurrent siphons of both Teredora and Uperotus

253 feature a single primary row of papillae, whereas the incurrent siphon of Tamilokus has an

254 additional secondary row that includes compound branched papillae; and, the cephalic hood in

255 both Teredora and Uperotus is inconspicuous, whereas the cephalic hood in Tamilokus is

256 prominent and covers the posterior slope of the shell valves. Finally, Tamilokus may be

257 recognized by the presence of the cephalic collar which is unique to this genus. Taxonomic

258 characters differentiating Tamilokus from Teredora and Uperotus are summarized in Table 2.

259

260

Tamilokus mabinia Shipway \& Distel, sp. nov.

261

urn:1sid:zoobank.org:act:88D193B6-9062-48C2-AC9D-EC6F858B3C05

262

263

264

265

266

267

268

Etymology: Mabinia (noun in apposition), in honour of Apolinario Mabini, a Philippine national hero, and pertaining to the type location of the specimens from Mabini, Batangas, Philippines.

Description: All characteristics of the genus, plus; dorsal anterior slope of shell valves highly elongated (Fig. 4B); incurrent and excurrent siphons ringed with papillae (Fig. 3F); incurrent siphon features outer ring of long papillae, and inner ring of shorter compound or branched papillae (Fig. 3G); siphon tips are ringed with pink to brownish red pigment that extends posteriorly in narrow closely spaced parallel stripes (Figs. 2A-C \& 3A). 
269 Definition: Pallets elongate, composed of an unsegmented blade built upon a central stalk (Fig.

270 4A); blade triangular, single concave U-shaped cup on distal margin with slightly more

271 pronounced curvature on outer face; periostracum absent; mantle collar flared, extending

272 approximately half the length of the pallet; stalk and blade approximately equal in length; stalk

273 translucent, ovate and flattened in both sagittal and transverse section; blade calcareous and

274 white.

276 Phylogeny

277 Bayesian analysis of concatenated small (18S) and large (28S) nuclear rRNA gene sequences

278 (Fig. S1) indicate a basal position for Tamilokus within Teredinidae, sharing a well-supported

279 node with Teredora, but separated from that taxon by a branch length comparable to those

280 separating most accepted teredinid genera. A subtree excerpted from Figure S1 is displayed in

281 Figure 6.

282

283 Discussion

284 Herein, we describe a divergent member of the Teredinidae that, based on anatomical,

285 morphological and molecular characteristics, is distinct from members of described genera.

286 Among the distinguishing features of Tamilokus mabinia, the most striking are the posterior

287 position of the stomach and the elongation of the crystalline style and style sac to accommodate

288 this posterior location. (Fig. 5A). This position of the stomach is found only in Tamilokus but is

289 similar to that found in Kuphus, except that in the latter, the entire visceral mass is located

290 posterior to the posterior adductor. The distinct positions of these two taxa on the phylogenetic

291 tree of Teredinidae suggests that this similarity is due to convergence rather than homology. The 
292 extension of the crystalline style, from a position ventral to and near the anterior end of the foot

293 to a position well posterior to the shell valves, is unique to Tamilokus (Turner 1966). In other

294 bivalves, cilia-mediated rotation of the crystalline style is thought to aid digestion by mixing

295 enzymes and reducing food particle size through mechanical action (Robin et al. , Nelson 1918,

296 Edmondson 1920, Yonge 1923, Lavine 1946, Morton 1952, Horiuchi et al. 1982, Alyakrinskaya

297 2001, Sakamoto et al. 2008, Mackenzie et al. 2014). However, the functional significance of the

298 exceptionally large style of Tamilokus remains to be explained.

Tamilokus also features a characteristic structure absent in other genera, which we term the

'cephalic collar'. This feature is formed by protruding folds of the mantle and is located directly

ventral to the foot and anterior adductor muscle and extends posterior to the shell valves on the

can be contracted or expanded, and Micro-CT scans reveal that the style sac is located within the

cephalic collar (Figs. 5A-B). These observations suggest that the cephalic collar may serve to

accommodate the large size of the crystalline style and may facilitate its movement.

307

Another unusual feature of Tamilokus is the caecum, which folds sharply to the right at its midpoint, doubling back upon itself to form a compressed U-shape. Among the Teredinidae, only two described genera, Teredora and Uperotus share this feature (Turner 1966). However,

Teredora and Uperotus differ from Tamilokus in several important ways. In these genera, the gills extend almost the entire length of the animal from the base of the siphons to the mouth, proportionately the longest gills among the family (Turner 1966). In addition to the extended 314 gills, the labial palps, which help sort and direct filtered particles to the mouth, are prominent 
315 and detached. This observation led to suggestions that these genera are specialized for

316 planktotrophy rather than wood feeding (Turner 1966, Nair et al. 1971). This hypothesis,

317 however, preceded the discovery of cellulolytic symbionts in the gills of shipworms, providing

318 the competing hypothesis that larger gills are adaptive for wood digestion (Distel, Amin et al.

319 2011).

320

321 In contrast to Teredora and Uperotus, the gills of Tamilokus extend only to the posterior end of

322 the caecum (Fig. 5A) and the palps are small, fixed, and appear to be vestigial. Also, in contrast

323 to these genera, the intestine of Tamilokus is extremely wide. In all specimens examined, the

324 capacious intestine was tightly packed with light-colored excavated wood fiber (Fig. 2B),

325 matching the color of the wood substrate in which the animals burrowed. No evidence of

326 planktonic organisms could be discerned in caecum contents or faecal material by microscopic

327 examination.

329 Siphon morphology also distinguishes Tamilokus from Teredora and Uperotus. The siphons of

330 the former are separate while those of the latter two are united along their entire length. The

331 presence of pink pinstripes on both the incurrent and excurrent siphons of Tamilokus (Figs. 2 \&

332 3) are also unique among described species. Additionally, the siphons are tipped with two rows

333 of papillae on the incurrent siphon aperture; the primary outer row is simple in structure, while

334 the inner secondary row include shorter compound papillae with multiple branches (Figs. 3F-G).

335 Characteristics of the siphons have been suggested as potentially useful in teredinid identification

336 (Turner 1966, Nair and Saraswathy 1971), but have been described for only a small number of 
337 species (Roch 1940, Turner 1966, Lopes et al. 1998, De Moraes et al. 2003). Although the

338 degree of genetic, ontogenetic and ecophenotypic variation in teredinid siphons has yet to be

339 documented (Turner 1966), characterizing these features could prove valuable for field

340 identification, as specimens could be studied in situ without the necessity of extracting the

341 teredinid from its burrow.

343 Aside from its unique anatomical and morphological features, the classification of Tamilokus as

344 a new genus is further supported by molecular phylogenetic data. Phylogenetic analysis based on

345 concatenated small (18S) and large (28S) nuclear rRNA gene sequences reveal well supported

346 relationships between Tamilokus and basal taxa within Teredinidae. However, the branch length

347 of Tamilokus is among the longest in the family, indicating divergence comparable to or greater

348 than those separating accepted teredinid genera (Fig. 6). Anatomical and morphological

349 characters are also consistent with the basal position of Tamilokus. As in other basal members of

350 the family, the stomach of T. mabinia is globular (Type 2 of Turner 1966 (Turner 1966)), the

351 intestine loops anteriorly over the crystalline style sac, and brooded larvae are absent in the gills

352 of all specimens examined. This is consistent with the hypothesis that these characteristics are

353 plesiomorphic and that the elongate stomach, absence of the anterior intestinal loop and complex

354 reproductive strategies are apomorphic (Distel, Amin et al. 2011).

355

356 In this investigation, Micro-CT has been invaluable for elucidating soft tissue anatomy. This has

357 been especially important in this systematically challenging group, which is characterised by

358 highly derived body parts and few taxonomically informative calcareous features. Previously,

359 Micro-CT has been used to determine quantitative measurements of wood degradation and

360 boring rates of Teredinidae (Amon et al. 2015). Additionally, Micro-CT has been used to reveal 
361 exceptionally well-preserved fossilized wood-boring bivalves in mid-Cretaceous wood, with

362 silicified soft parts and overall body-plan characteristic of the Teredinidae (Robin, Velasquez et

363 al.). Herein, we further demonstrate the power of this technique to reveal the relationships among

364 soft tissue features in three dimensions, and in the evaluation of likely mode of nutrition and life

365 history strategy, while minimizing distortion that can result from manual dissection.

366

367 The extent of diversity within the Teredinidae has long been a subject of debate. Historically, as many as 130 species have been recognized (Moll et al. 1931), but many were later synonymized in the first comprehensive work on the taxonomy of this family (Turner 1966). Recently, it has been suggested that teredinid diversity may be greater than previously thought (Huber, Langleit

371 et al. 2015, Shipway, O'Connor et al. 2016). This view is supported by the recent description of

372 one new genus and several new species of teredinid bivalves (Macintosh 2012, BORGES and

373 Merckelbach 2018, Velásquez and Shipway 2018). In addition, further reports suggest several

374 more species (Shipway, O’Connor et al. 2016, Treneman et al. 2018) and at least one more genus

375 (Lozouet et al. 2008) remain to be described.

376

\section{Conclusions}

378 We describe a new and anatomically divergent genus and species of wood-boring bivalve 379 (Teredinidae) from the Philippines, which we name Tamilokus mabinia. A detailed Micro-CT 3D render of T. mabinia reveals several anatomically divergent characters, including a new structure which we term the 'cephalic collar', a prominent crystalline style sac and crystalline style originating within the cephalic collar and extending beyond the posterior adductor muscle into

383 the posteriorly located stomach, and a caecum (wood-storing organ) which doubles back upon 
384 itself. In addition, the unique pallets, the primary taxonomic character of this family, could not

385 be placed in any existing genera. Phylogenetic analysis places T. mabinia in a separate taxon

386

387

388

389

390

391

392

393

394

395

396

397

398

399

400

401

402

403

404

405

406

407

408

409

410

411

412

413

414

415

416

among other basal members of the Teredinidae. The addition of Tamilokus raises the total

number of genera in this economically and environmentally important group of wood-boring

bivalves to 17 .

\section{Acknowledgments.}

The authors would like to thank Adam Baldinger and Jennifer Lenihan-Trimble (Museum of Comparative Zoology at Harvard University for use of the Keyence Microscope. The work was completed under supervision of the Department of Agriculture-Bureau of Fisheries and Aquatic Resources, Philippines (DA-BFAR) in compliance with all required legal instruments and regulatory issuances covering the conduct of the research.

\section{References}

Alyakrinskaya, I. (2001). "The dimensions, characteristics and functions of the crystalline style of molluscs." Biology Bulletin of the Russian Academy of Sciences 28(5): 523-535.

Amon, D. J., D. Sykes, F. Ahmed, J. T. Copley, K. M. Kemp, P. A. Tyler, C. M. Young and A. G. Glover (2015). "Burrow forms, growth rates and feeding rates of wood-boring Xylophagaidae bivalves revealed by micro-computed tomography." Frontiers in Marine Science 2: 10.

BORGES, L. M. and L. M. Merckelbach (2018). "Lyrodus mersinensis sp. nov.(Bivalvia: Teredinidae) another cryptic species in the Lyrodus pedicellatus (Quatrefages, 1849) complex." Zootaxa 4442(3): 441457.

Borges, L. M., H. Sivrikaya, A. Le Roux, J. Shipway, S. Cragg and F. Costa (2012). "Investigating the taxonomy and systematics of marine wood borers (Bivalvia: Teredinidae) combining evidence from morphology, DNA barcodes and nuclear locus sequences." Invertebrate Systematics 26(6): 572-582. Bulatov, G. (1933). "Eine neue Gattung aus der Familie der Teredinidae aus dem Japanischen Meer." Zoologischer Anzeiger 104: 165-176.

Charles, F., J. Coston-Guarini, J.-M. Guarini and S. Fanfard (2016). "Wood decay at sea." Journal of Sea Research 114: 22-25.

De Moraes, D. T. and S. G. Lopes (2003). "The functional morphology of Neoteredo reynei (Bartsch, 1920)(Bivalvia, Teredinidae)." Journal of molluscan studies 69(4): 311-318.

Distel, D. L. (2003). "The biology of marine wood boring bivalves and their bacterial endosymbionts." Wood deterioration and preservation 845: 253-271. 
417 Distel, D. L., M. Amin, A. Burgoyne, E. Linton, G. Mamangkey, W. Morrill, J. Nove, N. Wood and J. Yang 418 (2011). "Molecular phylogeny of Pholadoidea Lamarck, 1809 supports a single origin for xylotrophy 419 (wood feeding) and xylotrophic bacterial endosymbiosis in Bivalvia." Molecular Phylogenetics and 420 Evolution 61(2): 245-254.

421 Edmondson, C. H. (1920). "The reformation of the crystalline style in Mya arenaria after extraction." 422 Journal of Experimental Zoology 30(3): 259-291.

423 Horiuchi, S. and C. E. Lane (1982). "Carbohydrases of the crystalline style and hepatopancreas of 424 Strombus gigas linné." Comparative Biochemistry and Physiology 17(4): 1189-1197.

425 Huber, M., A. Langleit and K. Kreipl (2015). Compendium of bivalves 2, ConchBooks.

426 Lavine, T. F. (1946). "A study of the enzymatic and other properties of the crystalline style of clams:

427 evidence for the presence of a cellulase." Journal of cellular and comparative physiology 28(2): 183-195.

428 Lopes, S. and W. Narchi (1998). "Functional anatomy of Nausitora fusticula (Jeffreys, 1860)(Bivalvia:

429 Teredinidae)." The Veliger 41(3): 274-288.

430 Lozouet, P. and J. C. Plaziat (2008). "Mangrove environments and molluscs." Abatan River, Bohol and

431 Panglao Islands, Central Philippines. ConchBooks, Hackenheim.

432 Macintosh, H. (2012). "Lyrodus turnerae, a new teredinid from eastern Australia and the Coral Sea

433 (Bivalvia: Teredinidae)." Molluscan Research 32(1): 36.

434 Mackenzie, A. L. and C. Marshall (2014). "Proteins in the crystalline styles of the marine mussels Perna

435 canaliculus Gmelin and Mytilus galloprovincialis Lamarck." Journal of Shellfish Research 33(3): 673-685.

436 Medlin, L., H. J. Elwood, S. Stickel and M. L. Sogin (1988). "The characterization of enzymatically

437 amplified eukaryotic 16S-like rRNA-coding regions." Gene 71(2): 491-499.

438 Moll, F. and F. Roch (1931). "The Teredinidae of the British Museum, the natural history museums at

439 Glasgow and Manchester, and the Jeffreys collection." Journal of Molluscan Studies 19(4): 201-218.

440 Morton, J. (1952). "The role of the crystalline style." Journal of Molluscan Studies 29(2-3): 85-92.

441 Nair, N., B. (1966). "Ecology of marine founling and wood boring organisms of western Norway." Sarsia

442 8: 1-88.

443 Nair, N. B. and M. Saraswathy (1971). The Biology of Wood-Boring Teredinid Molluscs. Advances in

444 Marine Biology. S. R. Frederick and Y. Maurice, Academic Press. Volume 9: 335-509.

445 Nelson, T. C. (1918). "On the origin, nature, and function of the crystalline style of lamellibranchs."

446 Journal of Morphology 31(1): 53-111.

447 Nishimoto, A., T. Haga, A. Asakura and Y. Shirayama (2015). "An experimental approach for

448 understanding the process of wood fragmentation by marine wood borers in shallow temperate

449 waters." Marine Ecology Progress Series 538: 53-65.

450 Robin, N., M. Velasquez, A. Boura, G. Garcia, C. Jauvion, J. M. Boiteau, B. Gomez, V. Daviero-Gomez and

451 X. Valentin "The oldest shipworms (Bivalvia, Pholadoidea, Teredinidae) preserved with soft parts

452 (western France): insights into the fossil record and evolution of Pholadoidea." Palaeontology.

453 Roch, F. (1940). Die Terediniden des Mittelmeeres, Deutsch-Italienisches Institut für Meeresbiologie zu

454 Rovigno d'Istria.

455 Ronquist, F. and J. P. Huelsenbeck (2003). "MrBayes 3: Bayesian phylogenetic inference under mixed

456 models." Bioinformatics 19(12): 1572-1574.

457 Sakamoto, K., S. Uji, T. Kurokawa and H. Toyohara (2008). "Immunohistochemical, in situ hybridization

458 and biochemical studies on endogenous cellulase of Corbicula japonica." Comparative Biochemistry and

459 Physiology Part B: Biochemistry and Molecular Biology 150(2): 216-221.

460 Shipway, J., R. O’Connor, D. Stein, S. Cragg, T. Korshunova, A. Martynov, T. Haga and D. Distel (2016).

461 "Zachsia zenkewitschi (Teredinidae), a rare and unusual seagrass boring bivalve revisited and

462 redescribed." PloS one 11(5): e0155269. 
463 Treneman, N. C., L. M. Borges, J. R. Shipway, M. J. Raupach, B. Altermark and J. T. Carlton (2018). "A 464 molecular phylogeny of wood-borers (Teredinidae) from Japanese Tsunami Marine Debris." Aquatic 465 Invasions 13(1): 101-112.

466 Turner, R. D. (1966). "A survey and illustrated catalogue of the Teredinidae (Mollusca: Bivalvia)." A

467 survey and illustrated catalogue of the Teredinidae (Mollusca: Bivalvia).

468 Turner, R. D. (1988). Cellulolytic nitrogen-fixing bacteria in the Teredinidae (Mollusca: Bivalvia).

469 Biodeterioration 7, Springer: 743-748.

470 Turner, R. T. (1966). "A survey and illustrated catalogue of the Teredinidae." Spec. publ. Museum of

471 Comparative Zoology.

472 Velásquez, M. and J. R. Shipway (2018). "A new genus and species of deep-sea wood-boring shipworm 473 (Bivalvia: Teredinidae) Nivanteredo coronata n. sp. from the Southwest Pacific." Marine Biology

474 Research: 1-10.

475 Voight, J. R. (2015). "Xylotrophic bivalves: aspects of their biology and the impacts of humans." Journal 476 of Molluscan Studies 81(2): 175-186.

477 Yonge, C. (1923). "Studies on the Comparative Physiology of Digestion: I.--The Mechanism of Feeding, 478 Digestion, and Assimilation in the Lamellibranch Mya." Journal of Experimental Biology 1(1): 15-64. 
Figure 1

Specimen collection site:

A, map of collection site and B, overview of geographic location. Scale bar $=0.5 \mathrm{~km}$.

*Note: Auto Gamma Correction was used for the image. This only affects the reviewing manuscript. See original source image if needed for review.

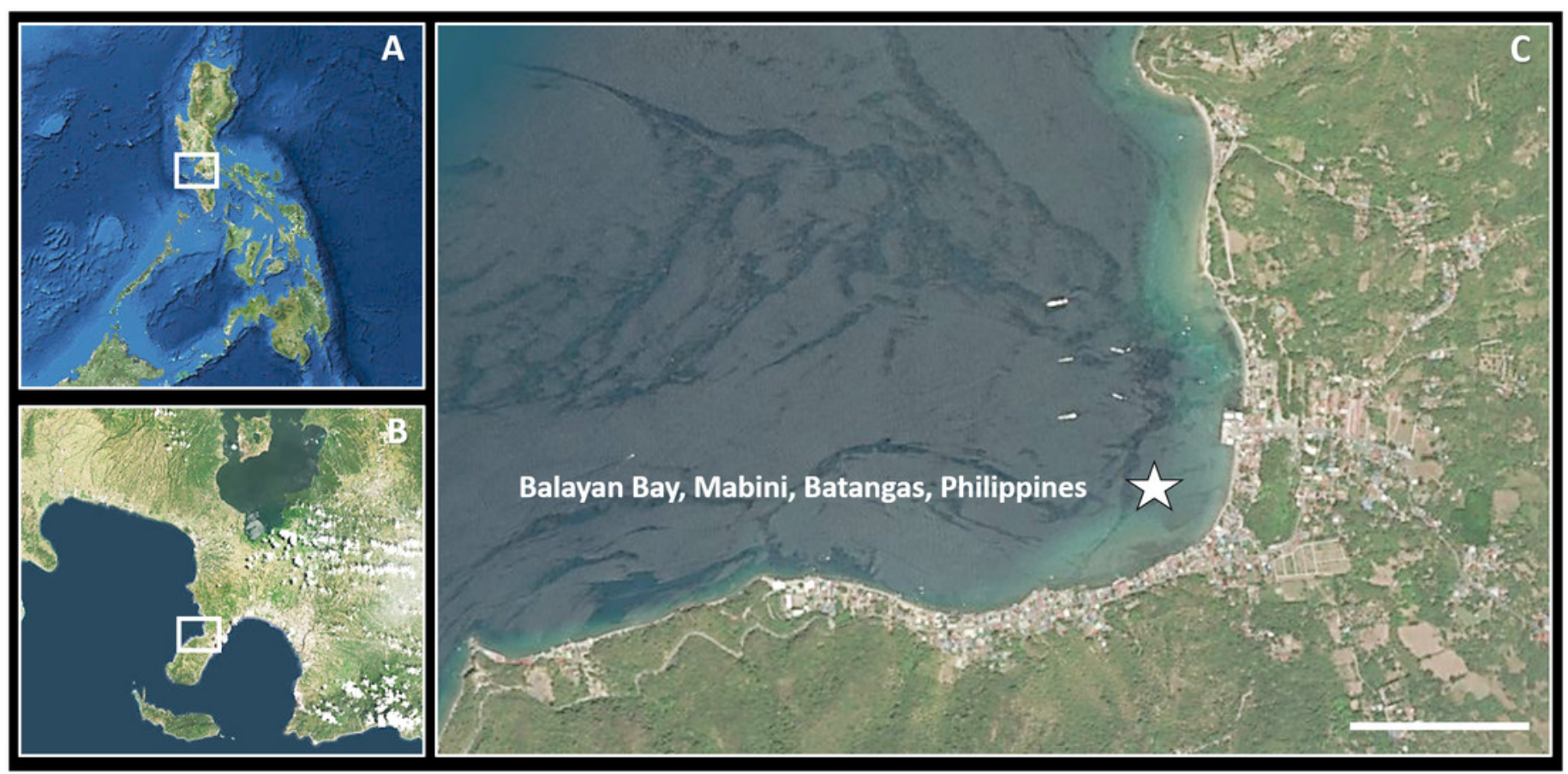


Figure 2 (on next page)

Tamilokus mabinia:

A, Holotype (PMS-3916Y); B, paratype (PMS-3915X); C, paratype (PMS-4051L). Ca, caecum;

CC, cephalic collar; CH, cephalic hood; DG, digestive glands; Ft, foot; Gi, gill; In, Intestine; MC, mantle collar; Pa, pallet; Si, siphon; St, Stomach; SV, shell valve. Scale bar $=1.0 \mathrm{~cm}$. 
A

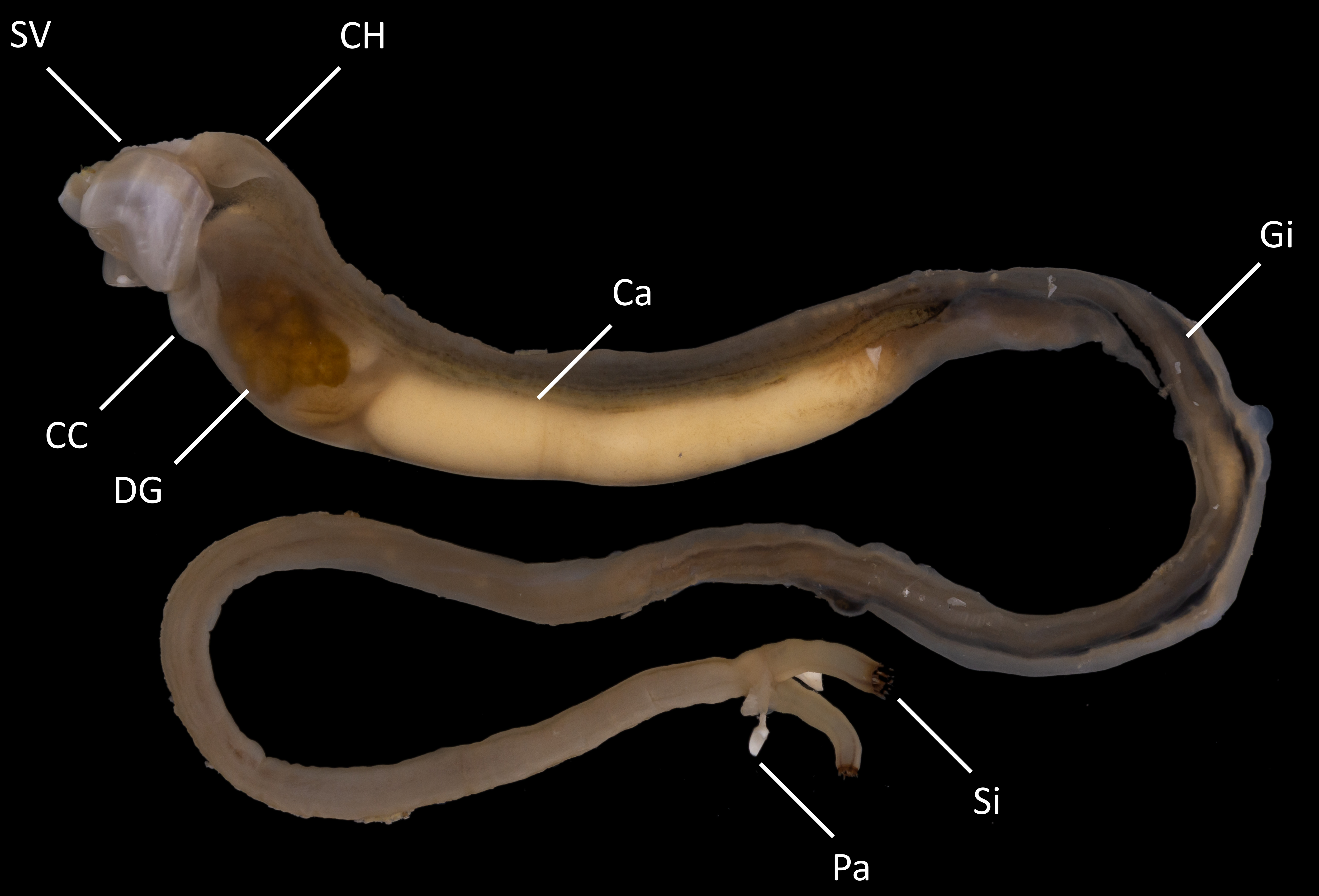

C

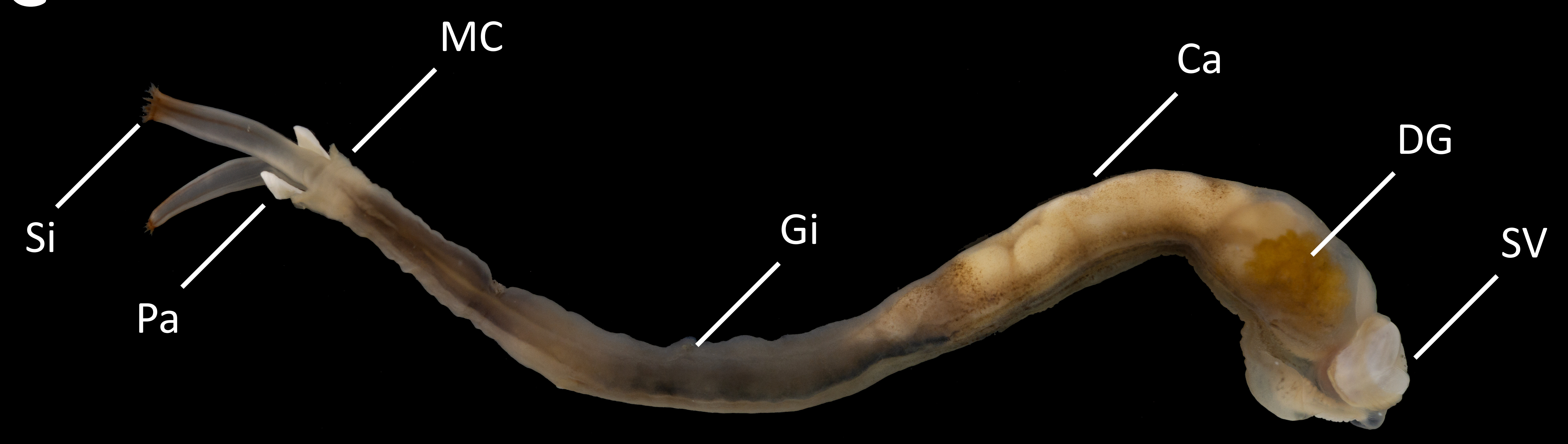

B

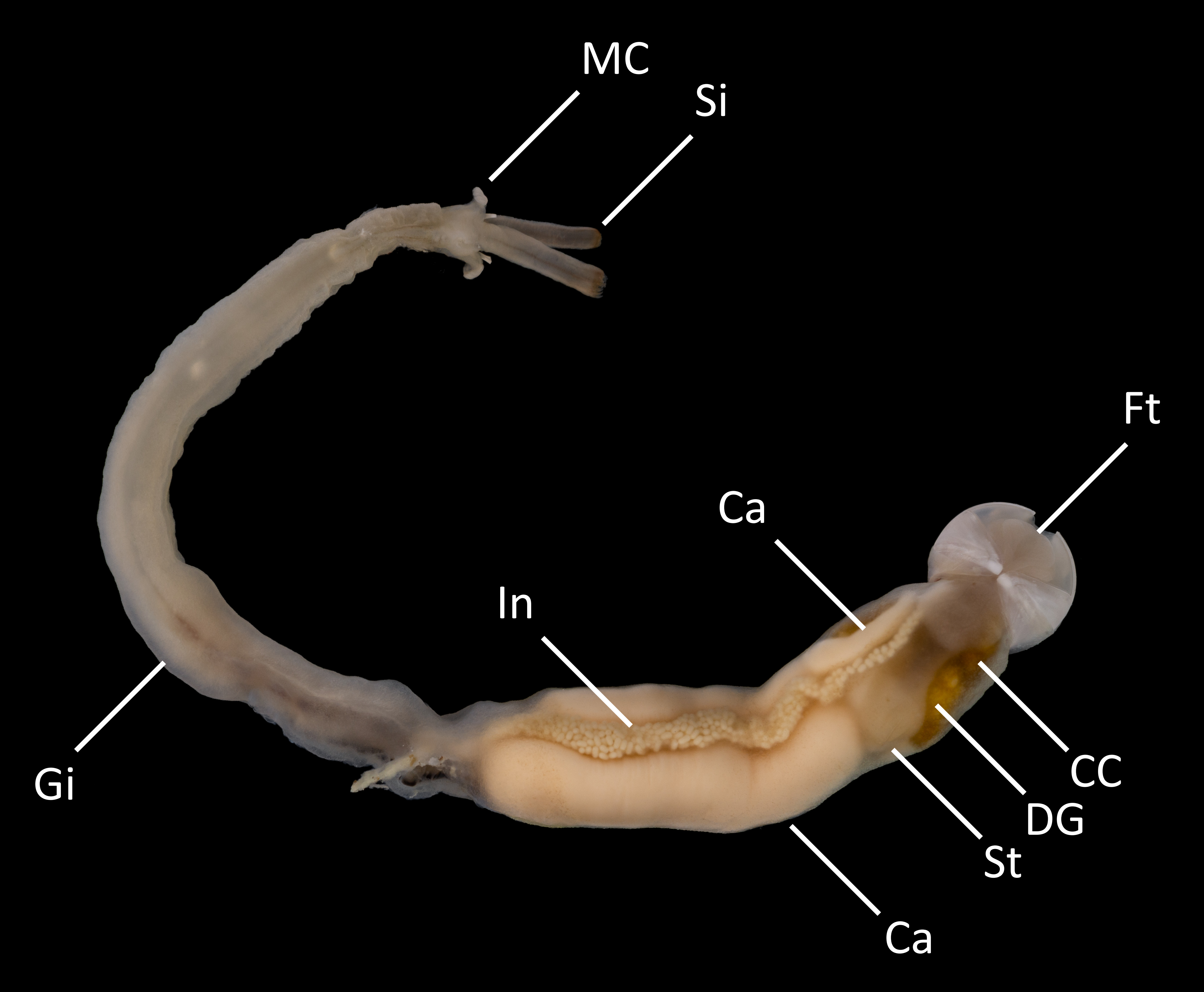


Figure 3 (on next page)

Morphological characters of Tamilokus mabinia:

A, Tamilokus mabinia major morphological characters (PMS-3949Y). Scale bar $=5.0 \mathrm{~mm} ; \mathrm{B}-\mathrm{C}$, cephalic hood; D-E, cephalic collar; F, siphon features; $G$, magnified region of the incurrent siphon. Scale bar $=500 \mu \mathrm{m} . \mathrm{CC}$, cephalic collar; CH, cephalic hood; ES, excurrent siphon; Ft, foot; IP, inner papillae; IS, incurrent siphon; MC, mantle collar; Pa, pallet; OP, outer papillae; $\mathrm{Si}$, siphon. 


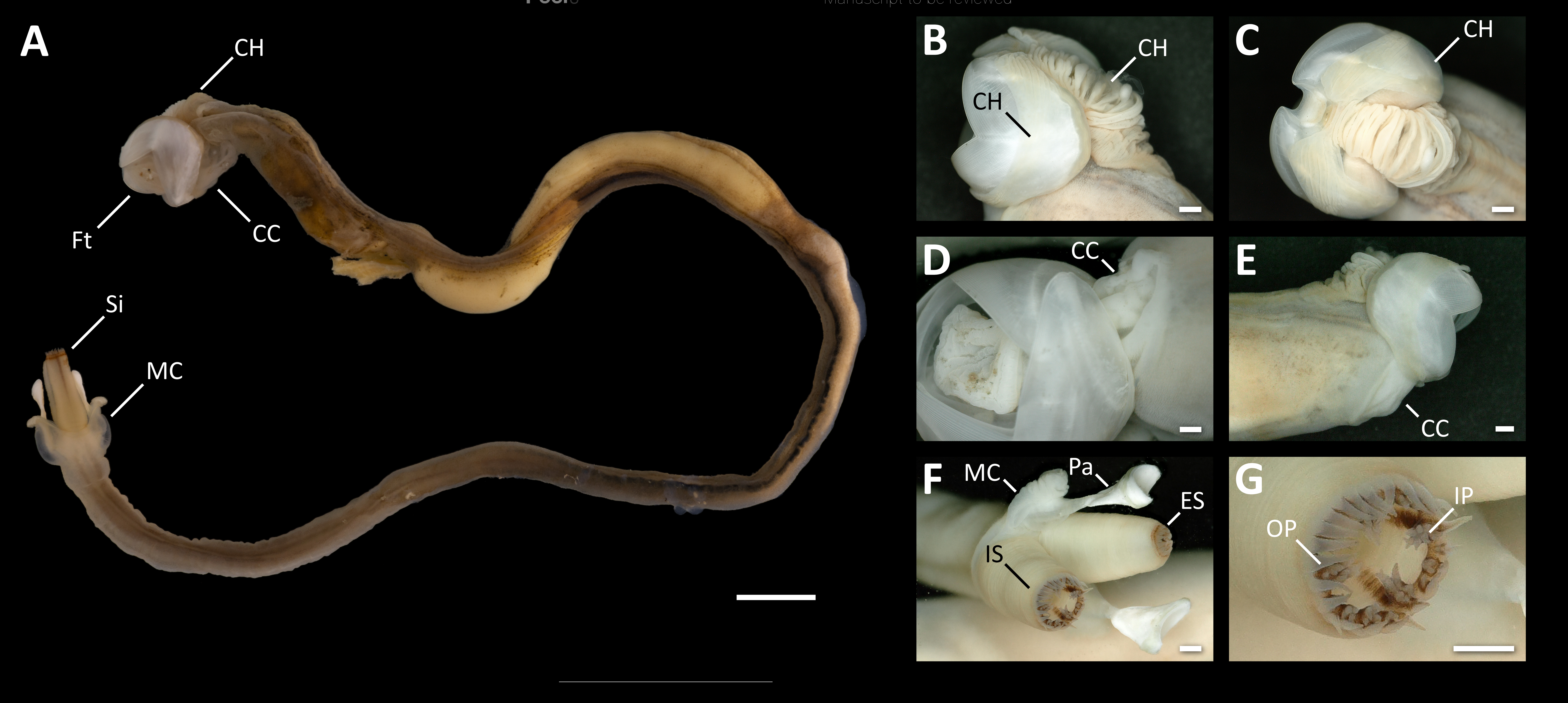




\section{Figure 4}

Calcareous structures of Tamilokus mabinia:

A, Inner surface (left) and outer surface (right) of pallet. Specimen PMS-3943P. Scale bar = $1.0 \mathrm{~mm}$; B, shell valve outer surface. Specimen PMS-3915X. Scale bar $=500 \mu \mathrm{m}$. The valves are very thin and brittle. Note that the ventral tip of the valve is damaged. Anterior to left, dorsal is toward top.

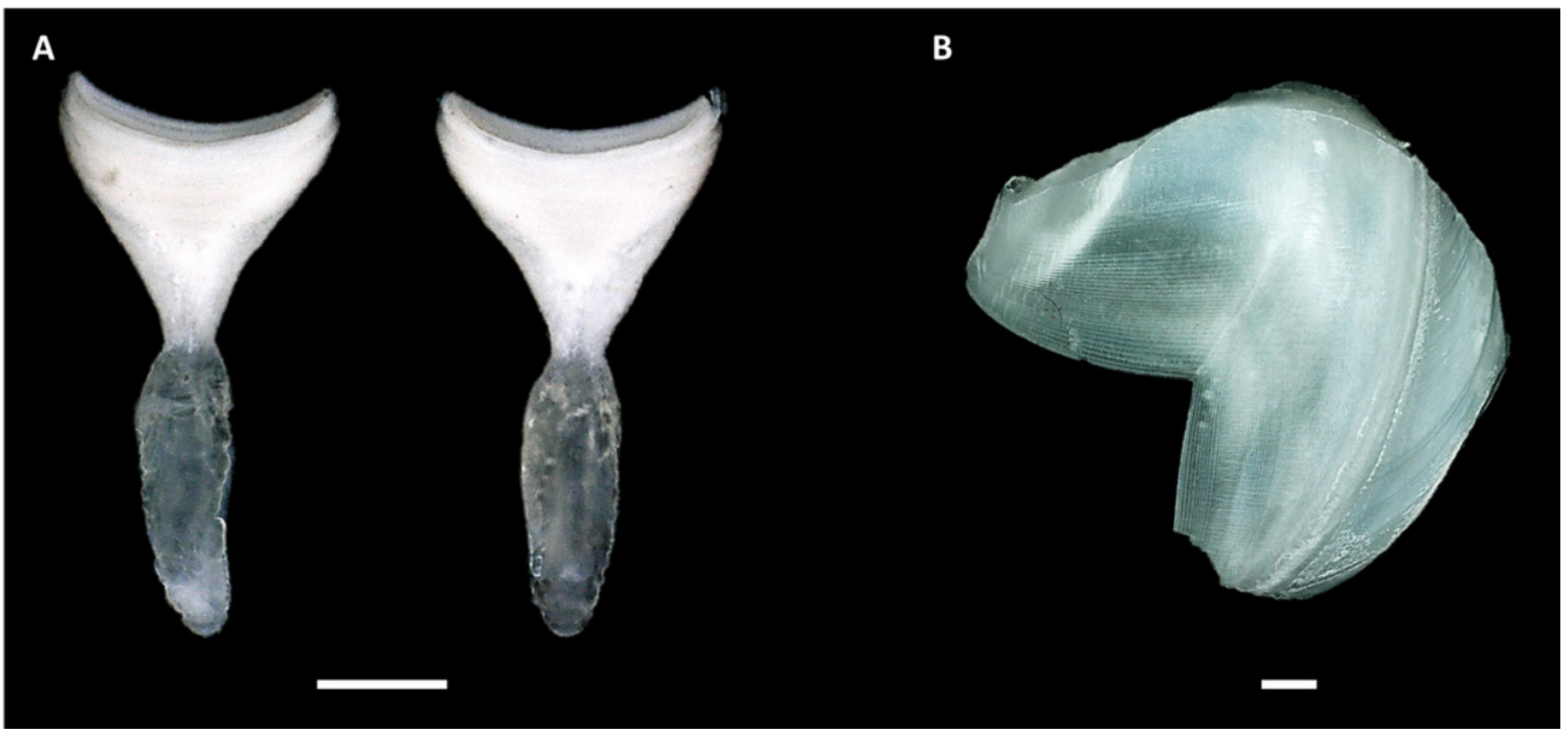


Figure $\mathbf{5}$ (on next page)

Microcomputed Tomography 3D render of Tamilokus mabinia:

A, major anatomical structures; $B$ - $M$ transverse sections of $A$ from anterior to posterior. $A C$, anal canal; $\mathrm{Ca}$, caecum; $\mathrm{CC}$, cephalic collar; $\mathrm{CH}$, cephalic hood; CS, crystalline style; CSS, crystalline style sac; DG, digestive gland; EBV, efferent branchial vein; Ft, foot; Gi, gill; Go, gonad; He, heart; In, intestine; MC, mantle collar; MO, mouth; Oe, oesophagus; PAM, posterior adductor muscle; SCA; stomach-caecum aperture; Si, siphon; St, stomach; SV, shell valve. Specimen PMS-4051L. Scale bar $=2.5 \mathrm{~mm}$. 
A

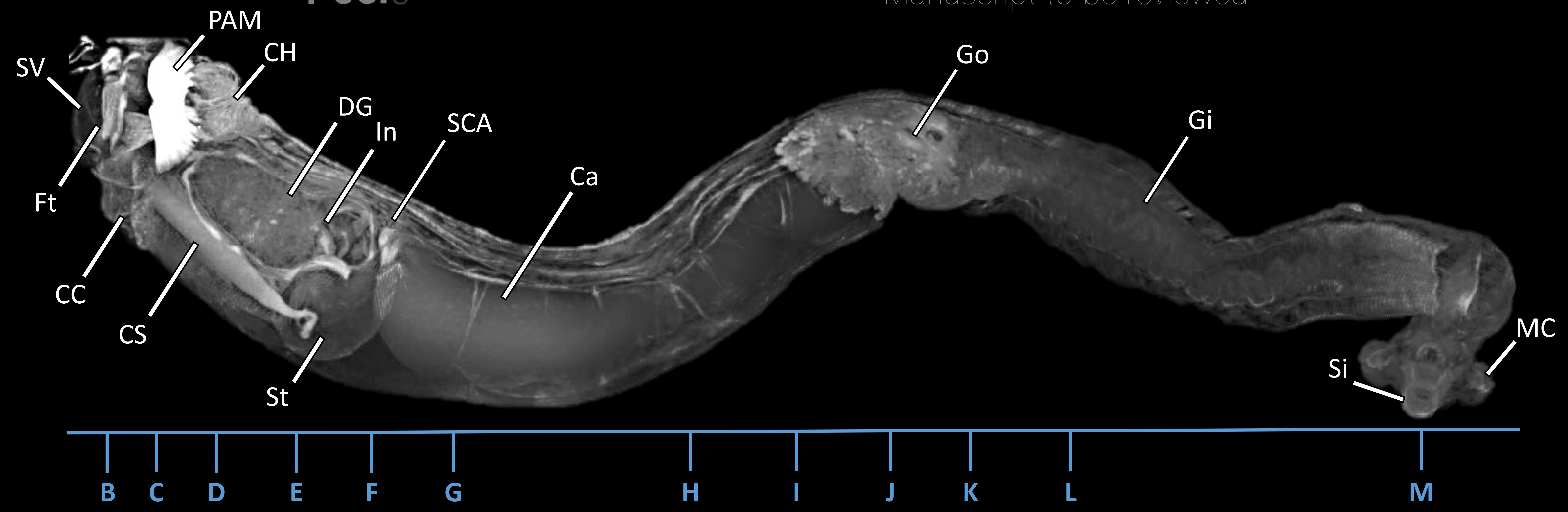

B

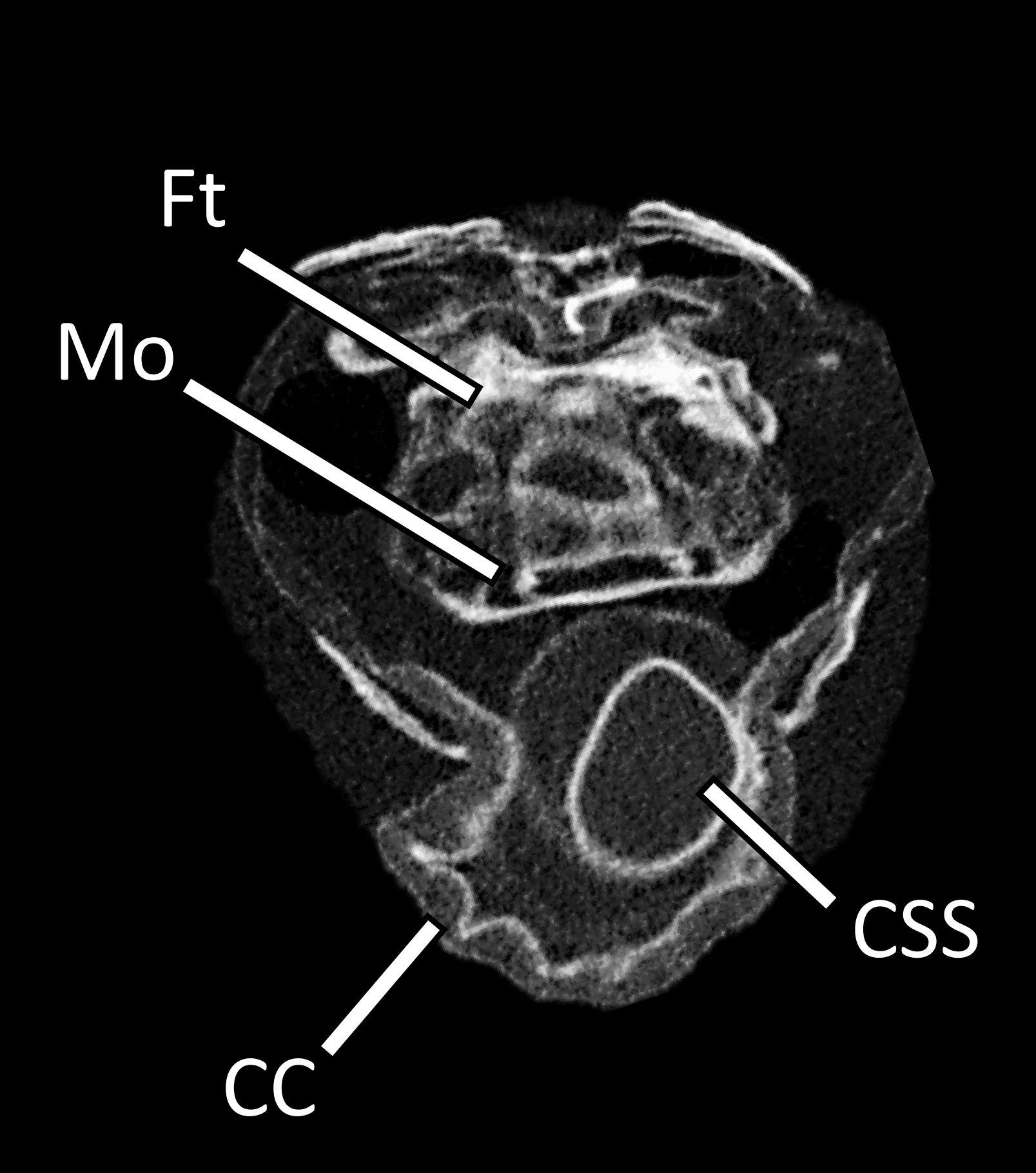

H

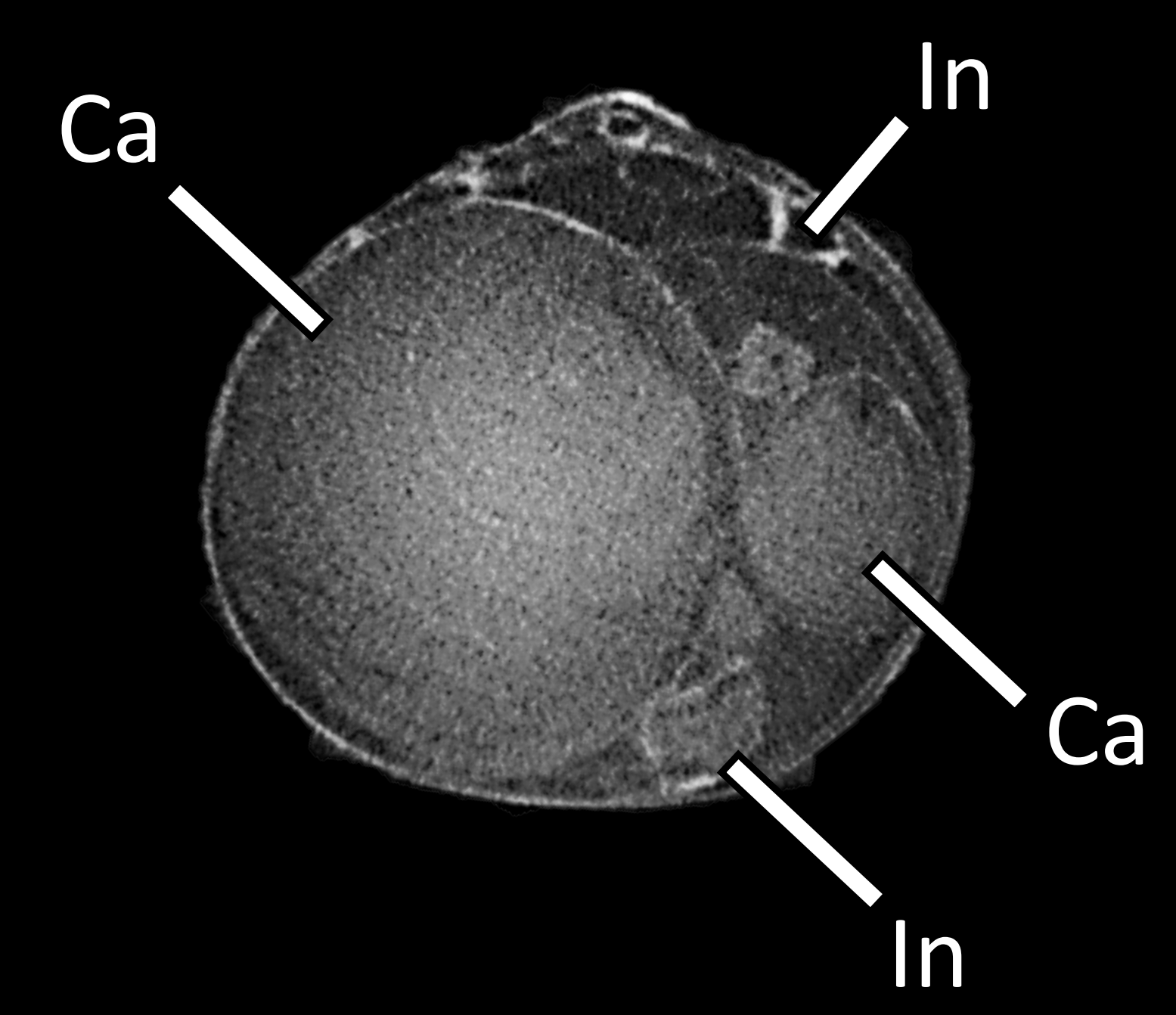

C

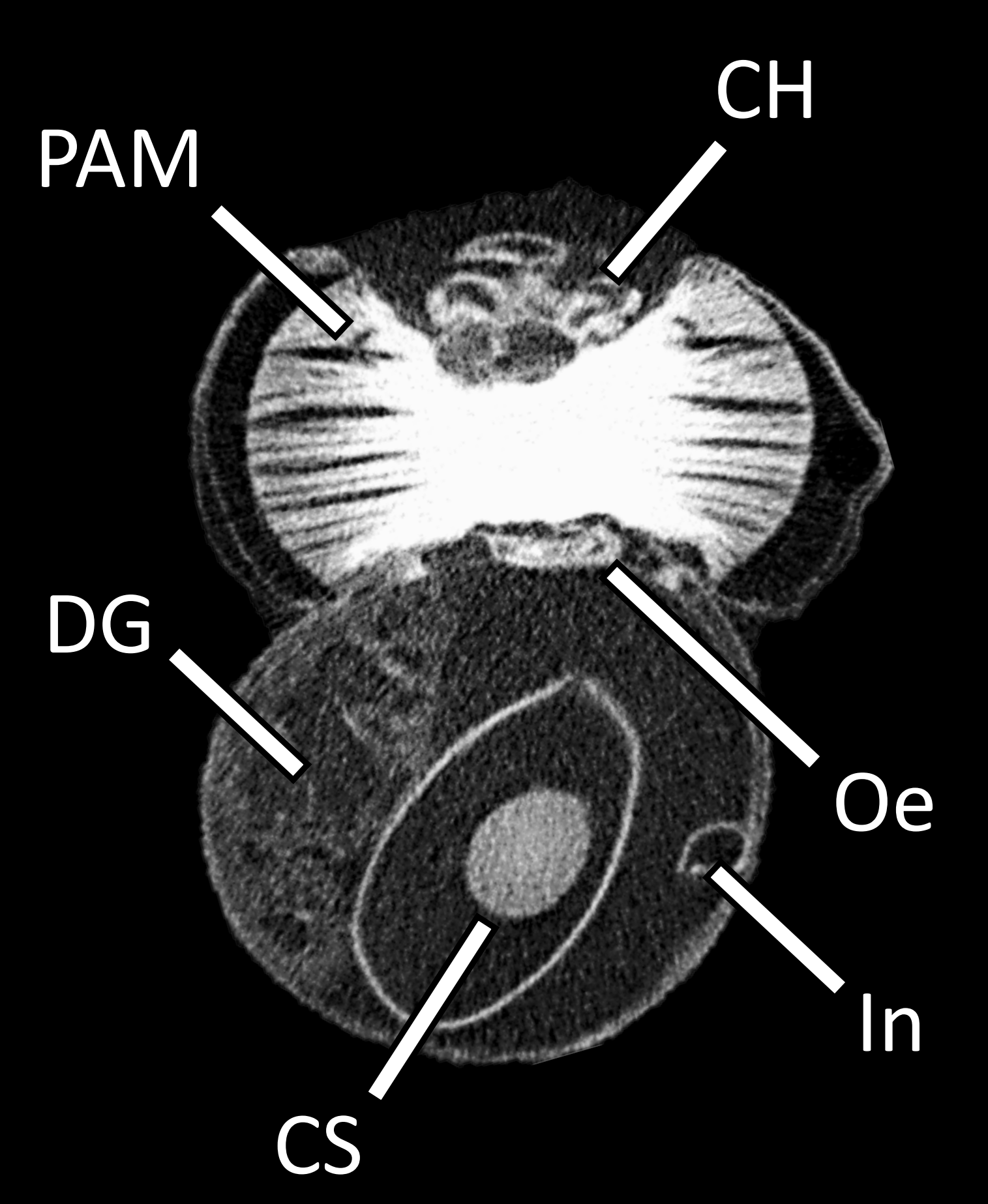

I

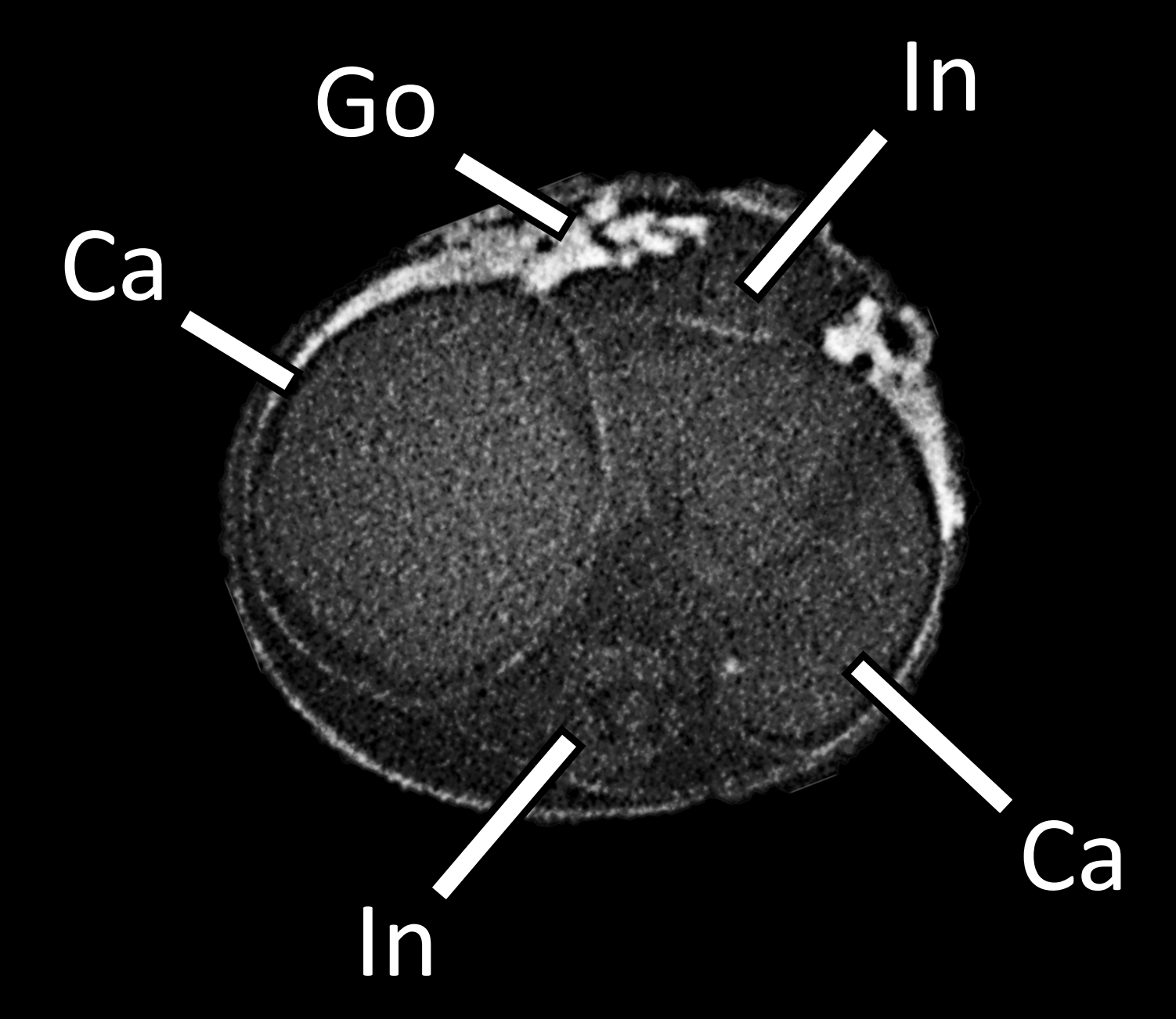

D

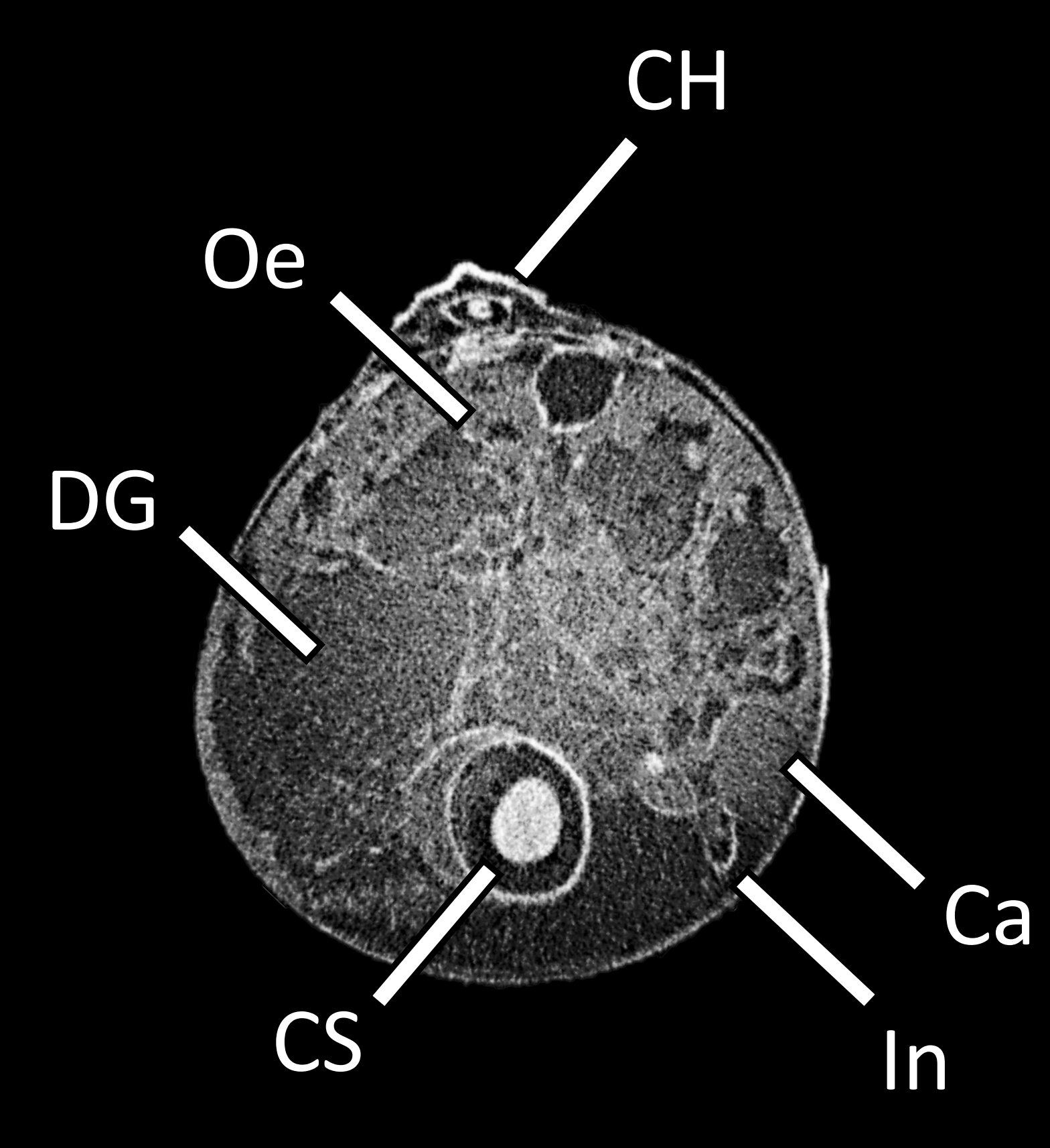

J

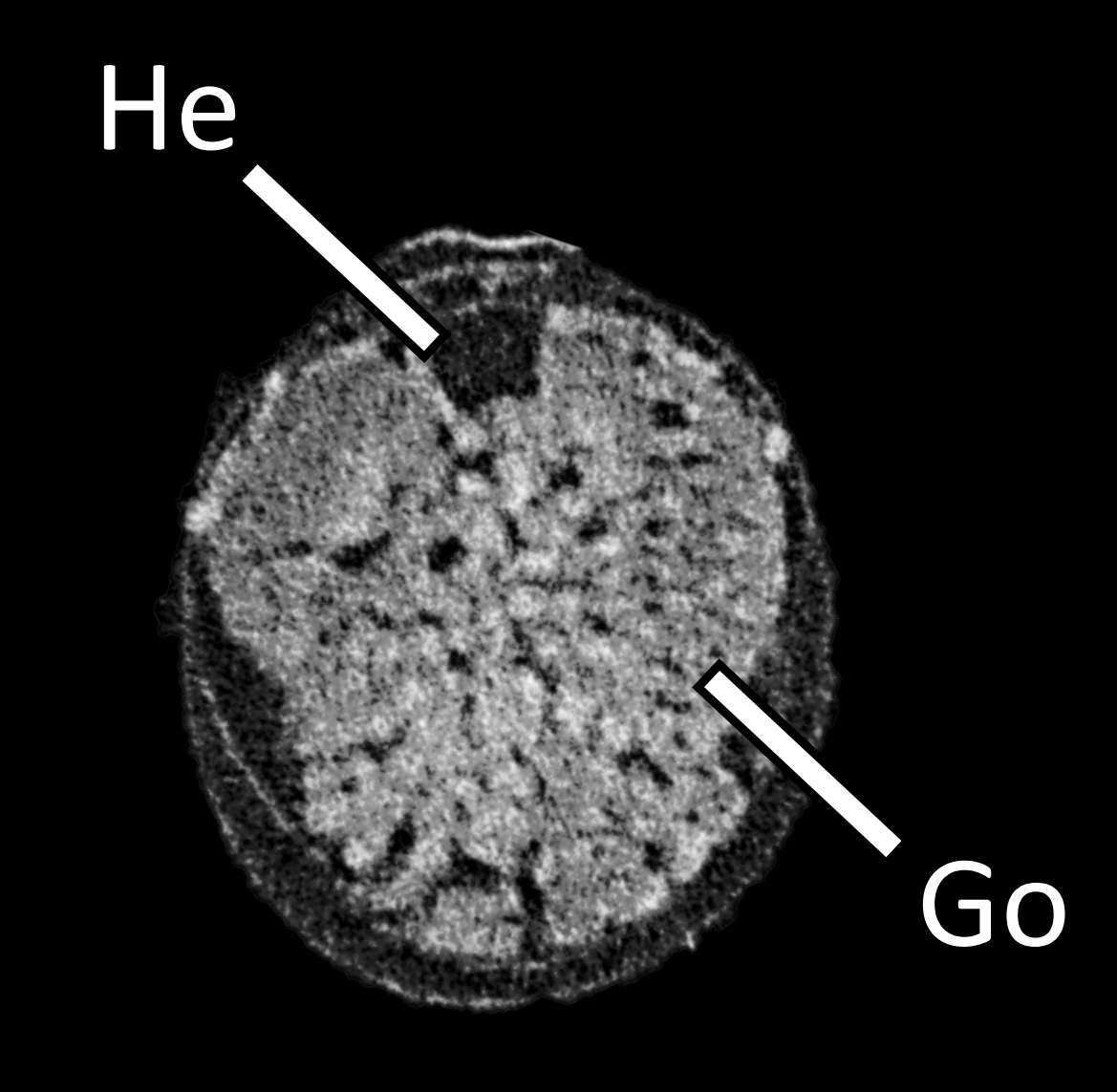

E

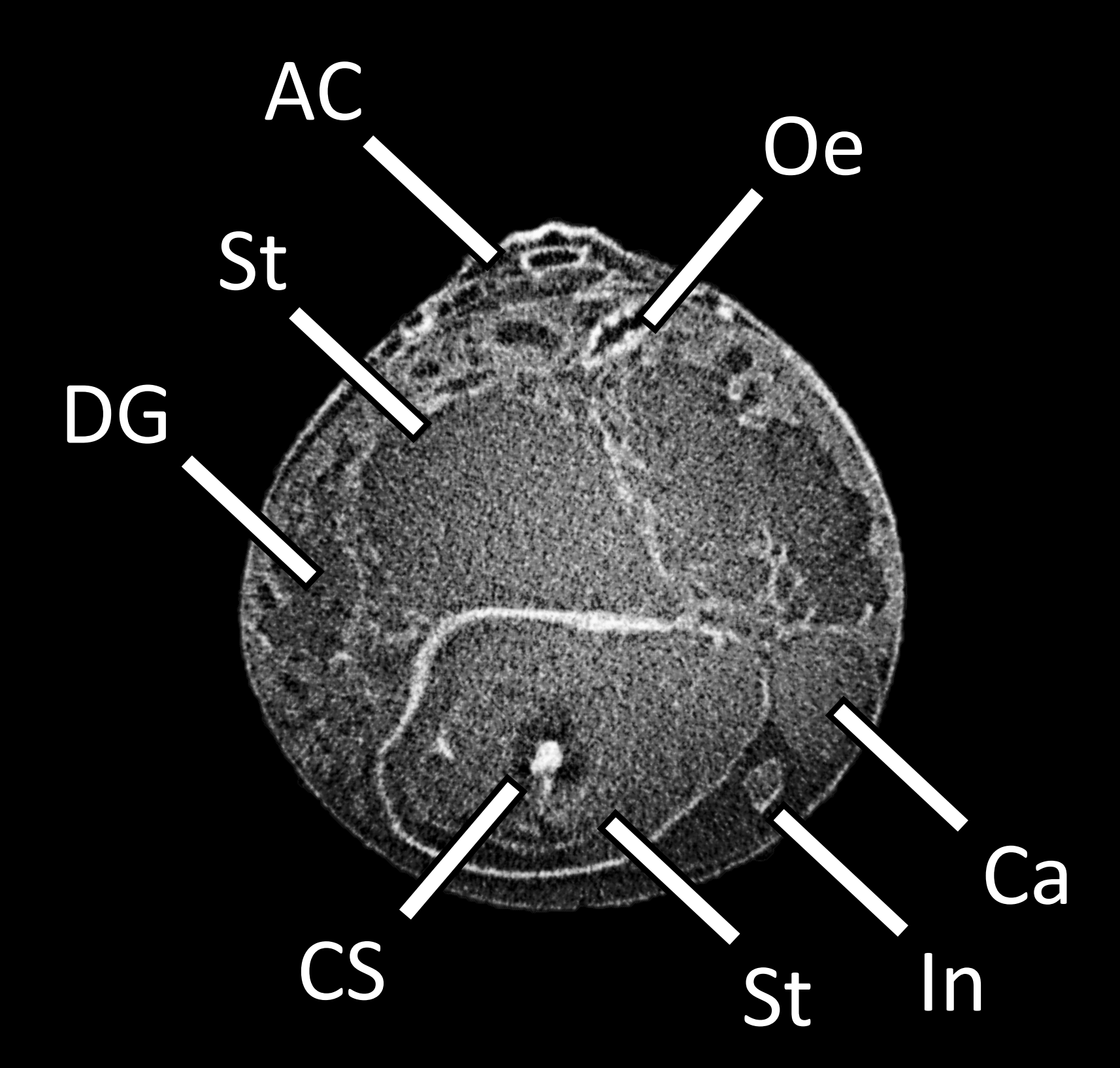

K

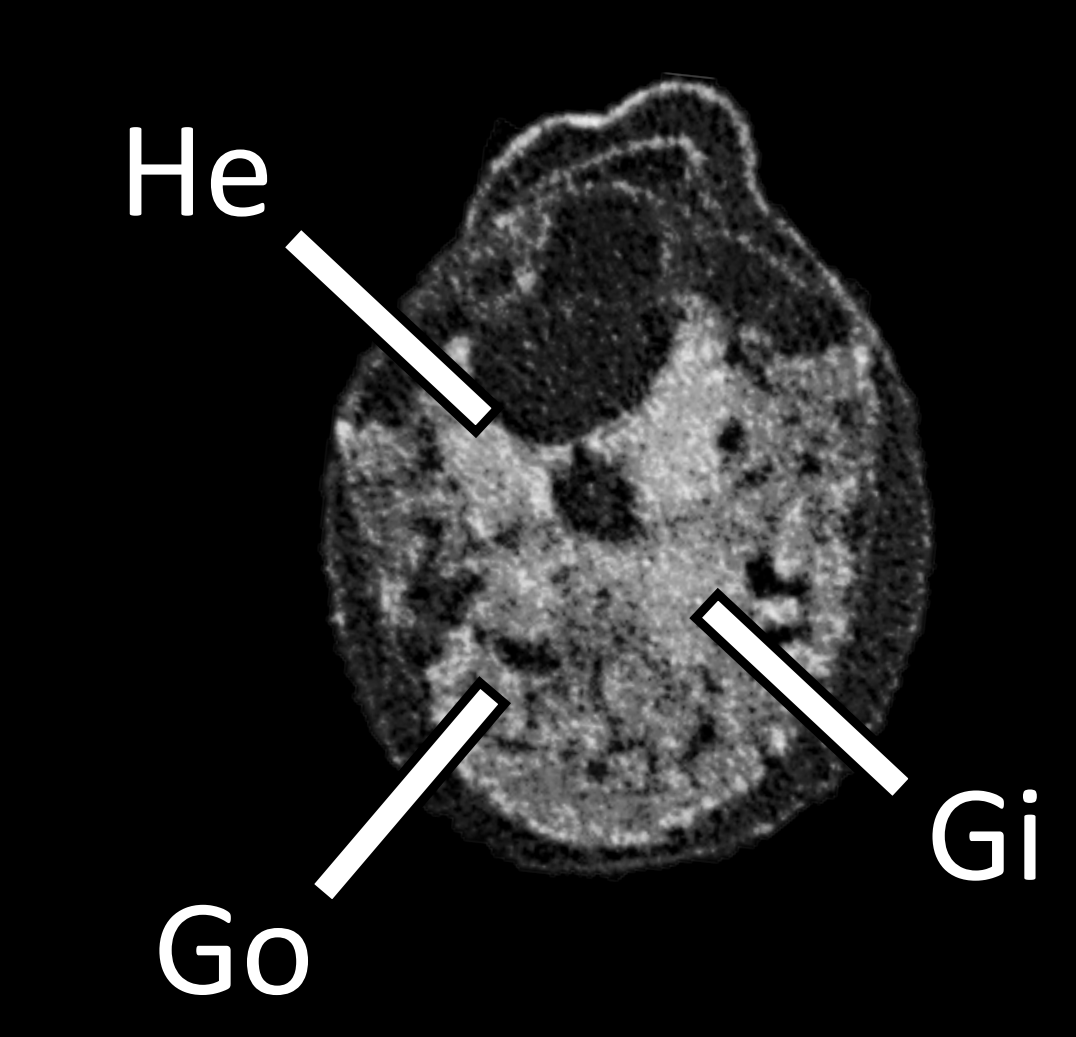

F

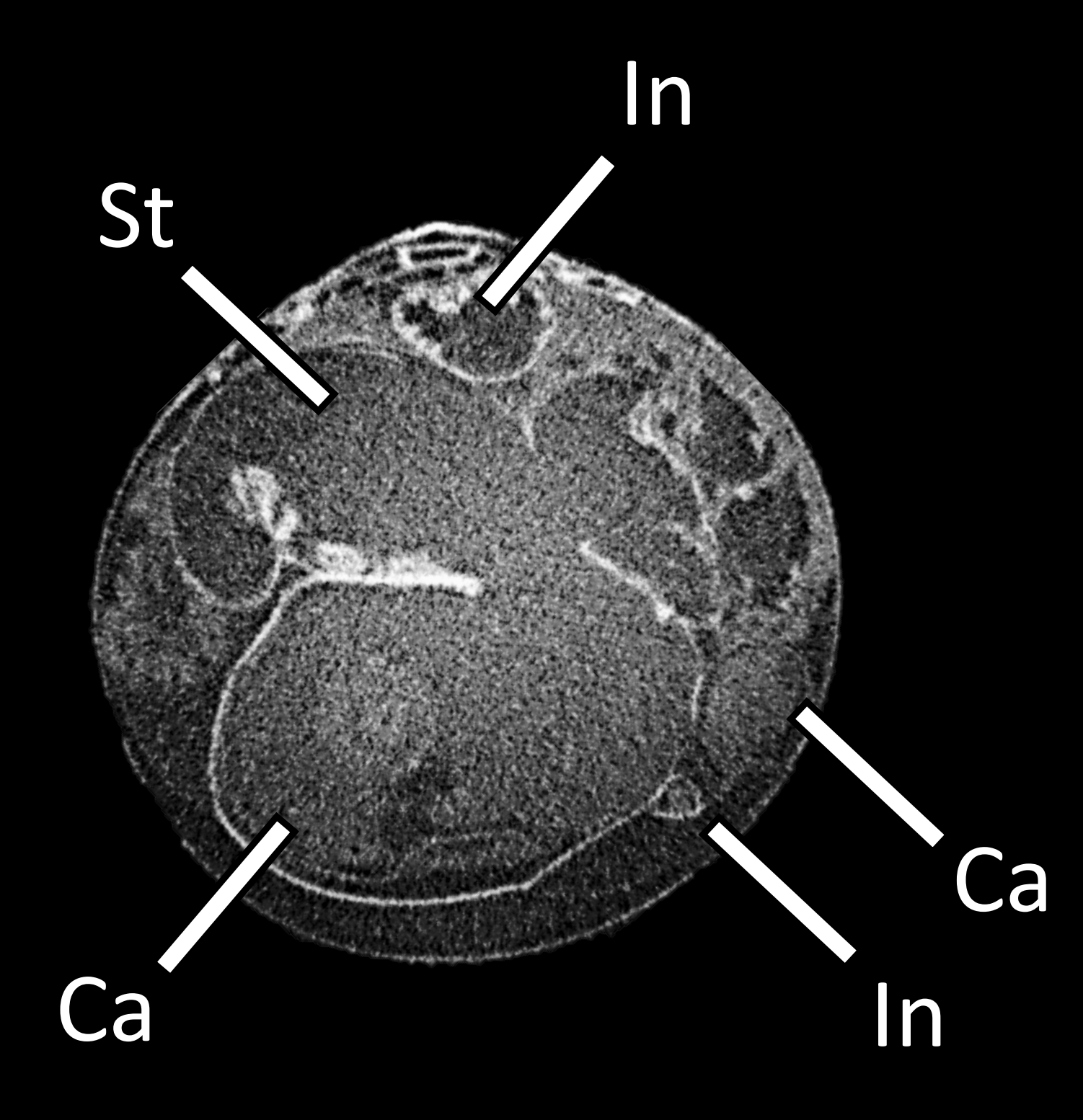

L

M

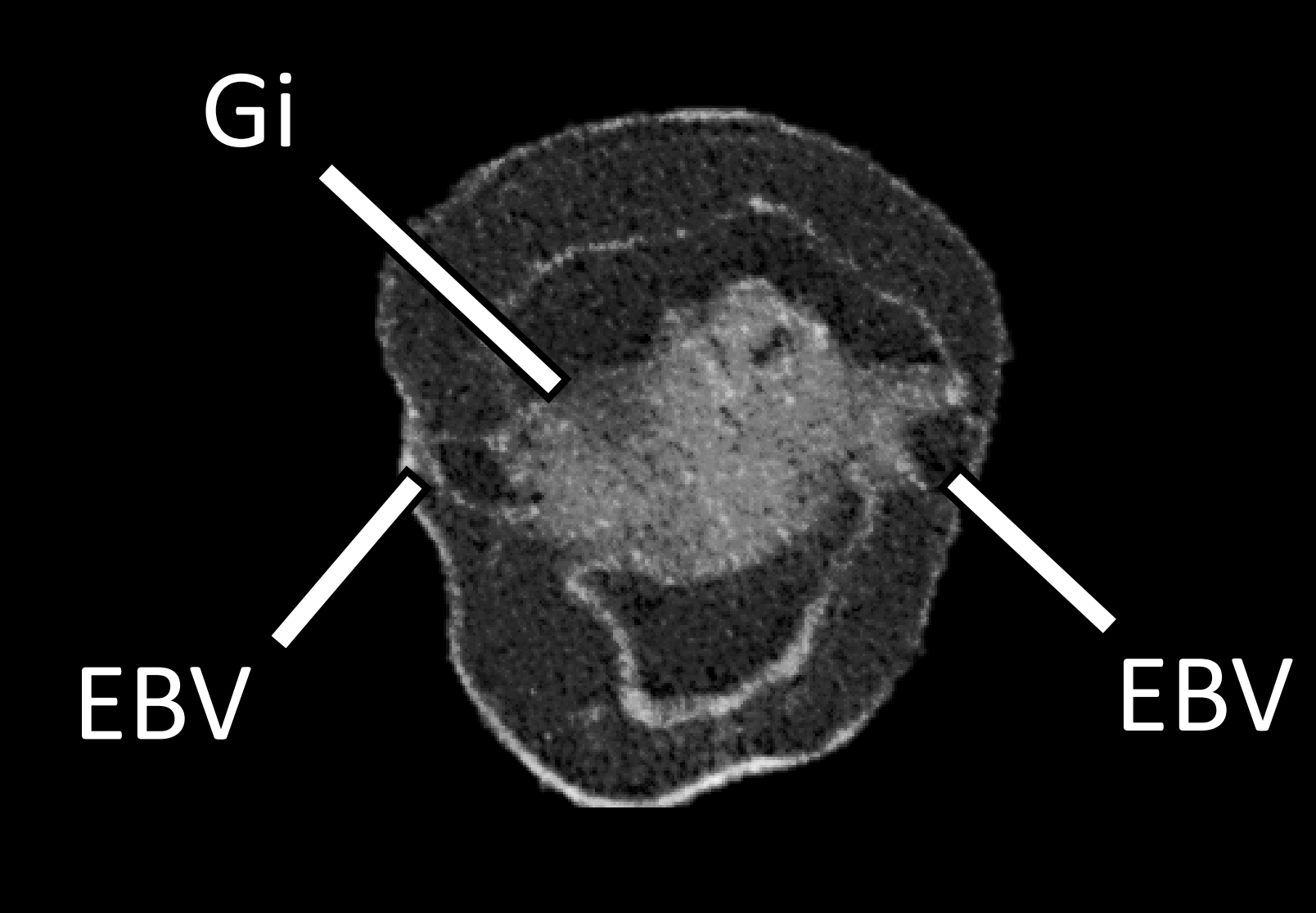

$\mathbf{G}$
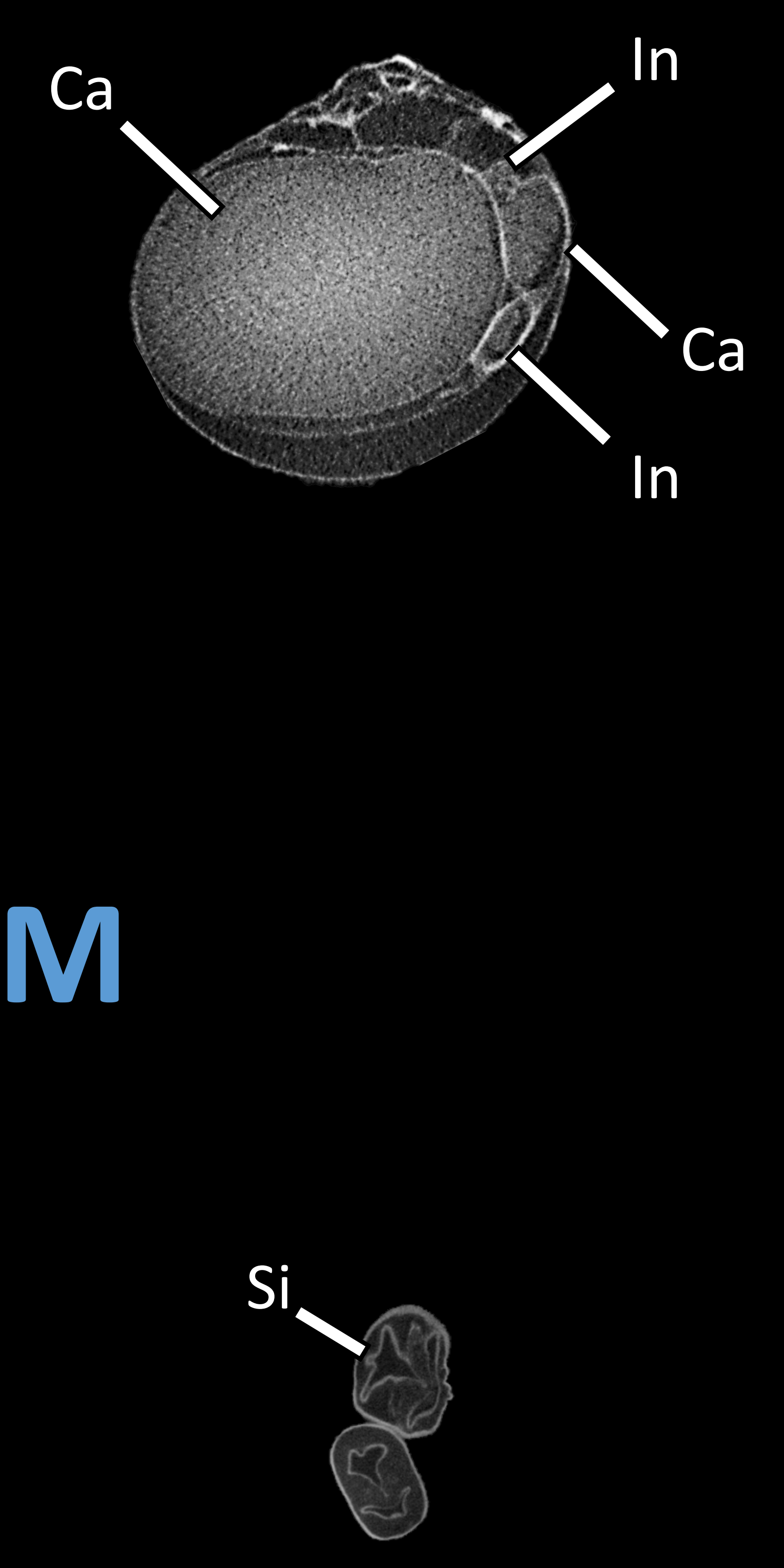
Figure 6 (on next page)

Phylogenetic position of Tamilokus mabinia among the Teredinidae:

A sub tree excerpted from a Bayesian analysis of the concatenated $18 \mathrm{~S}$ and $28 \mathrm{~S}$ nuclear rRNA gene sequences obtained from specimen PMS-3943P. The tree was constructed using the taxa presented in Distel et al., (2011). The full tree is presented in Supplemental Figure 1. Numbers at nodes indicate posterior 


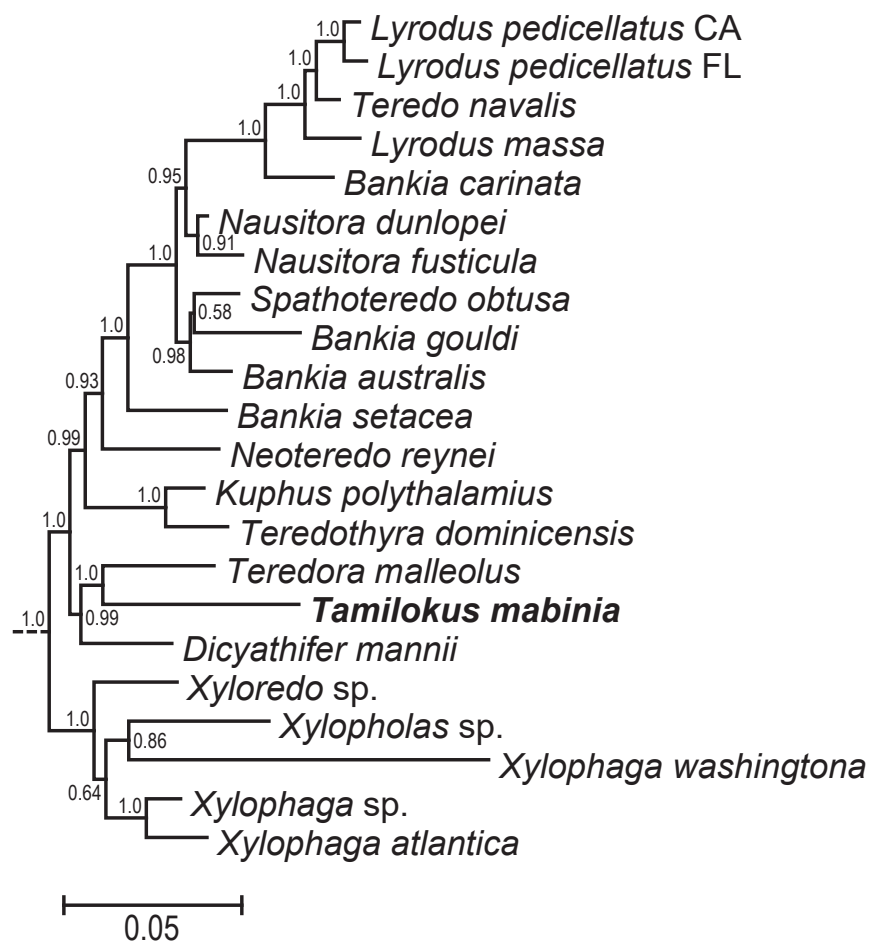




\section{Table $\mathbf{1}$ (on next page)}

Specimen details and collection site information.

*The holotype will be transferred to the National Museum of the Philippines pending completion of an ongoing reorganization. †Partial specimen with missing valves. 
Table 1. Specimen details and collection site information.

\begin{tabular}{|c|c|c|c|c|c|}
\hline $\begin{array}{l}\text { Specimen } \\
\text { Number }\end{array}$ & $\begin{array}{l}\text { Holding } \\
\text { Institution }\end{array}$ & $\begin{array}{l}\text { Accession } \\
\text { Number }\end{array}$ & Type & Preparation & Figure \\
\hline PMS-3899P & MSI & PMS-3899P & Paratype & Preserved in $70 \%$ ethanol & - \\
\hline PMS-3915X & ANSP & A476699 & Paratype & Preserved in $70 \%$ ethanol & Figs. 2B \& 4B \\
\hline PMS-3916Y* & ANSP & A476699 & Holotype & Preserved in $70 \%$ ethanol & Fig. 2A \\
\hline PMS-3943P† & MSI & PMS-3943P & Paratype & Preserved in $70 \%$ ethanol & Figs. 4A \& 6 \\
\hline PMS-3943P† & OGL & E28692 & - & Genomic DNA voucher & Fig. 6 \\
\hline PMS-3949Y & MSI & PMS-3949Y & Paratype & Preserved in $70 \%$ ethanol & Fig. 3 \\
\hline PMS-4037Y & ANSP & A476699 & Paratype & Fixed in $4 \%$ PFA, transferred to $70 \%$ ethanol & - \\
\hline PMS-4051L & ANSP & A476699 & Paratype & Fixed in $4 \%$ PFA, transferred to $70 \%$ ethanol, stained with $10 \%$ iodine for Micro-CT. & Figs. 2C \& 5 \\
\hline
\end{tabular}

4 *The holotype will be transferred to the National Museum of the Philippines pending completion of an ongoing reorganization.

5 Partial specimen with missing valves. 
Table 2 (on next page)

Diagnostic characters of all teredinid genera featuring a U-shaped caecum. 
Table 2: Diagnostic characters of all teredinid genera featuring a U-shaped caeca.

\begin{tabular}{|c|c|c|c|}
\hline $\begin{array}{l}\text { Taxonomic } \\
\text { character }\end{array}$ & $\begin{array}{l}\text { Tamilokus [Shipway, Rosenberg } \\
\text { \& Distel, 2018] }\end{array}$ & Teredora [Bartsch, 1921] & Uperotus [Guettard, 1770] \\
\hline Labial palps & Reduced/absent & Free & Large and free \\
\hline $\begin{array}{l}\text { Crystalline } \\
\text { style }\end{array}$ & $\begin{array}{l}\text { Extends from base of foot beyond } \\
\text { posterior adductor muscle }\end{array}$ & $\begin{array}{l}\text { Located anterior to posterior } \\
\text { adductor muscle }\end{array}$ & $\begin{array}{l}\text { Located anterior to posterior } \\
\text { adductor muscle }\end{array}$ \\
\hline Stomach & $\begin{array}{l}\text { Globular, located posterior to } \\
\text { posterior adductor muscle }\end{array}$ & $\begin{array}{l}\text { Globular, located anterior to } \\
\text { posterior adductor muscle }\end{array}$ & $\begin{array}{l}\text { Globular, located anterior to } \\
\text { posterior adductor muscle }\end{array}$ \\
\hline Caecum & $\begin{array}{l}\text { Doubles back upon itself, to the } \\
\text { right }\end{array}$ & $\begin{array}{l}\text { Doubles back upon itself, to the } \\
\text { right }\end{array}$ & $\begin{array}{l}\text { Doubles back upon itself, to the } \\
\text { right }\end{array}$ \\
\hline $\begin{array}{l}\text { Caecal } \\
\text { typhlosole }\end{array}$ & Absent & Rudimentary & Absent \\
\hline Heart & Median position & Located anteriorly & Located anteriorly \\
\hline Gills & $\begin{array}{l}\text { Located posteriorly, extending to } \\
\text { posterior caecum }\end{array}$ & $\begin{array}{l}\text { Extend from base of siphons to } \\
\text { mouth }\end{array}$ & $\begin{array}{l}\text { Extend from base of siphons to } \\
\text { mouth }\end{array}$ \\
\hline Siphons Form & $\begin{array}{l}\text { Separated along entire length, pink } \\
\text { pinstriped pigmentation }\end{array}$ & United to the tip & United to the tip \\
\hline $\begin{array}{l}\text { Incurrent } \\
\text { siphon papillae }\end{array}$ & $\begin{array}{l}\text { Primary row numerous small } \\
\text { papillae, secondary row compound } \\
\text { papillae }\end{array}$ & $\begin{array}{l}\text { Incurrent siphon numerous large } \\
\text { papillae }\end{array}$ & $\begin{array}{l}\text { Incurrent siphon numerous small } \\
\text { papillae }\end{array}$ \\
\hline $\begin{array}{l}\text { Excurrent } \\
\text { siphon papillae }\end{array}$ & Numerous small papillae & - & $\begin{array}{l}\text { Excurrent siphon two large papillae } \\
\text { on dorsal surface }\end{array}$ \\
\hline Cephalic hood & $\begin{array}{l}\text { Prominent, covers valve posterior } \\
\text { slope }\end{array}$ & $\begin{array}{l}\text { Inconspicuous, does not cover valve } \\
\text { posterior slope }\end{array}$ & $\begin{array}{l}\text { Inconspicuous, does not cover valve } \\
\text { posterior slope }\end{array}$ \\
\hline Cephalic collar & Present & Absent & Absent \\
\hline Mantle collar & Surrounds siphons and pallet stalks & Absent & Absent \\
\hline Pallets & $\begin{array}{l}\text { Triangular, cup-shaped, non- } \\
\text { segmented, ovate flattened stalk }\end{array}$ & $\begin{array}{l}\text { Paddle shaped, non-segmented, } \\
\text { 'thumbnail' depression }\end{array}$ & $\begin{array}{l}\text { Paddle shaped, non-segmented, } \\
\text { 'thumbnail' depression, radiating } \\
\text { ribs }\end{array}$ \\
\hline
\end{tabular}

